\title{
A Educação Financeira nos cursos de formação inicial de professores de matemática das Universidades Públicas do Estado de São Paulo
} Jéssica Rocha Batista

\author{
DISSERTAÇÃO APRESENTADA AO \\ INSTITUTO DE MATEMÁTICA E \\ ESTATÍSTICA DA UNIVERSIDADE DE SÃO \\ PAULO PARA OBTENÇÃO DO TÍTULO DE \\ MESTRE EM CIÊNCIAS
}

Programa: Mestrado Profissional em Ensino de Matemática Orientador: Professor Dr. David Pires Dias 


\title{
A Educação Financeira nos cursos de formação inicial de professores de matemática das Universidades Públicas do Estado de São Paulo
}

\begin{abstract}
Esta versão da dissertação contém as correções e alterações sugeridas pela comissão julgadora durante a defesa da versão original do trabalho, realizada em 12/11/2019. Uma cópia da versão original está disponível no Instituto de Matemática e Estatística da Universidade de São Paulo.
\end{abstract}

Comissão Julgadora:

- Professor Doutor David Pires Dias (orientador) - IME - USP

- Professor Doutor Márcio Fabiano da Silva - UFABC

- Professora Doutora Raquel Milani - FE - USP 
"Porque o Senhor dá a sabedoria; da sua boca é que vem o conhecimento e o entendimento." Provérbios 2:6 


\section{AGRADECIMENTOS}

Agradeço, primeiramente a Deus, meu Senhor e Fortaleza, por sempre fornecer força, esperança, sabedoria e conhecimento diante da minha caminhada.

Ao meu esposo, meu parceiro, por sempre estar ao meu lado, me apoiando e me tolerando em todos os momentos da minha vida, juntos somos fortes.

A minha família por ser sempre a minha fortaleza e a minha base, pois sem eles nada disso seria possível.

Aos meus colegas de classe, pelas brincadeiras, piadas, risadas e principalmente pela troca de conhecimento constante durante todo o curso, pois de alguma maneira contribuíram nesta etapa da minha vida.

A todos os professores, mas em especial a professora Iole de Freitas Druck por ter me auxiliado na busca de um professor que pudesse me auxiliar no tema da minha pesquisa.

E por fim, ao meu orientador, sem palavras, professor David Pires Dias, obrigada por todo o auxílio constante, suporte, momentos de conversas e paciência, porque foi enriquecedor trabalhar contigo. Muito obrigada por todo apoio e motivação durante todo esse tempo.

Obrigada a todos. 


\section{RESUMO}

BATISTA, J. J. A Educação Financeira nos cursos de formação inicial de professores de matemática das Universidades Públicas do Estado de São Paulo. 2017. Dissertação (Mestrado) - Instituto de Matemática e Estatística, Universidade de São Paulo, São Paulo, 2017.

O presente trabalho tem como principal objetivo analisar se e como a Educação Financeira é tratada nos cursos de formação inicial dos professores de matemática das Universidades Públicas do Estado de São Paulo. Com esse intuito serão analisadas as atuais grades curriculares dos cursos de licenciatura em matemática e e questionários com licenciados em matemática oriundos dessas Universidades.

Palavras-chave: Educação Financeira, Formação Inicial de Professores de Matemática, Universidades Públicas do Estado de São Paulo. 


\begin{abstract}
BATISTA, J. J. A Educação Financeira nos cursos de formação inicial de professores de matemática das Universidades Públicas do Estado de São Paulo. 2017. Dissertação (Mestrado) - Instituto de Matemática e Estatística, Universidade de São Paulo, São Paulo, 2017.

The present work has as main objective to analyze how the Financial Education is treated in the initial formation courses of mathematics teachers of the Public Universities of the State of São Paulo. To this end, it will be analyzed as the current curriculum series of undergraduate mathematics courses and questionnaires with mathematics qualifications or courses from these universities.
\end{abstract}

Keywords: Financial Education, Initial Teacher Training in Mathematics, Public Universities of the State of São Paulo. 


\section{SUMÁRIO}

RESUMO .............................................................................................................................. iii

ABSTRACT .................................................................................................................................iv

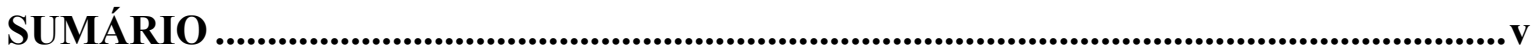

LISTA DE ABREVIATURAS ............................................................................................vi

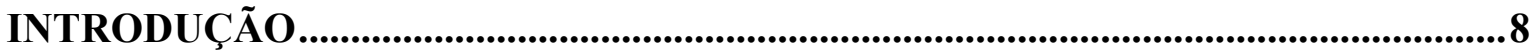

1 EDUCAÇÃO FINANCEIRA............................................................................12

2 ANÁLISE DO CURRÍCULO DOS CURSOS DE LICENCIATURA EM

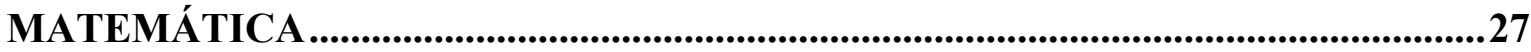

$2.1 \quad$ A primeira etapa da pesquisa .............................................................................................39

$2.2 \quad$ A segunda etapa da pesquisa ............................................................................................. 43

3 RESULTADOS ……........................................................................................................46

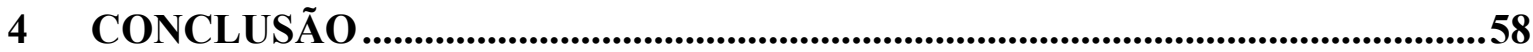

5 APÊNDICES ....................................................................................61

APÊNDICE A - Questionário aplicado aos alunos ...........................................................62

APÊNDICE B - Transcrição da entrevista com a docente ................................................67

6 REFERÊNCIAS BIBLIOGRÁFICAS................................................................74 


\section{LISTA DE ABREVIATURAS}

BMF - Bolsa de Mercadorias e Futuros

BMF - Bolsa de Mercadorias e Futuros

BNCC - Base Nacional Comum Curricular

CONSED - Conselho Nacional de Secretários de Educação

DCN - Diretrizes Curriculares Nacionais

EF - Educação Financeira

ENEF - Estratégia Nacional de Educação Financeira

FEBRABAN - Federação Brasileira de Bancos

LDB - Lei de Diretrizes e Bases da Educação

MEC - Ministério da Educação

MF - Matemática Financeira

OCDE - Organização para Cooperação e Desenvolvimento Econômico

PCN - Parâmetros Curriculares Nacionais de Matemática

PIB - Produto Interno Bruto

PNE - Plano Nacional de Educação

UFABC - Universidade Federal do ABC

UFSCar - Universidade Federal de São Carlos

UNDIME - União Nacional dos Dirigentes Municipais de Educação

UNESP - Universidade Estadual Paulista Júlio de Mesquita Filho

UNICAMP - Universidade Estadual de Campinas

UNIFESP - Universidade Federal de São Paulo

USP - Universidade de São Paulo 


\section{INTRODUÇÃO}

A ideia deste trabalho surgiu da curiosidade e consequente necessidade de analisar se a Educação Financeira é tratada em cursos de formação inicial de professores de matemática e, caso seja, como tal tema é abordado em sala de aula.

No ano de 2016, o Brasil estava em um grave cenário de crise econômica, sendo assim, o tema de consumo e Educação Financeira foram incluídos na Lei de Diretrizes e Bases da Educação (LDB). Também verificamos em outros normativos da educação brasileira a existência do devido tema, logo, vimos que o tema consta explicitamente na Base Nacional Comum Curricular (BNCC) e implicitamente nos Parâmetros Curriculares Nacionais de Matemática (PCNs de Matemática), porém nas Diretrizes Curriculares Nacionais (DCNs) não constam nenhuma abordagem, seja explícita ou implícita, do tema.

Devido ao tema de Educação Financeira ter sido abordado recentemente em diretrizes voltadas à educação brasileira, é necessário observar e quem sabe melhorar a formação dos professores que lecionam a matemática e, portanto, Matemática Financeira, para que os mesmos tenham capacidade e possibilidade de tratar também da Educação Financeira. De acordo com os autores TEIXEIRA, COUTINHO (2015), o professor de matemática muitas vezes não recebe uma formação específica em Matemática Financeira.

\footnotetext{
Sintetizando, um problema que permeia as pesquisas é a observação de que o professor de matemática não recebe ou pouco recebe uma formação específica em Matemática Financeira. Pelo fato de o ensino da Educação Financeira se encontrar em fase de implementação no Brasil, seguindo os exemplos dos Estados Unidos, Europa e Japão, se faz necessário melhorar a formação dos professores que lecionam Matemática Financeira, objetivando conectar essa disciplina à Educação Financeira. (TEIXEIRA, COUTINHO, 2015, p.5)
}

Já de acordo com ALMEIDA (2004), para que a Matemática Financeira seja ensinada aos alunos, é desejável que os professores estejam preparados e seguros do que aprenderam durante a sua formação inicial a fim de transmitir o aprendizado adiante, sendo assim, a capacitação dos professores é fundamental para que a Educação Financeira seja ensinada dentro da sala de aula em diversos níveis escolares.

Embasados pela necessidade, supracitada, do tema na formação inicial de professores fomos analisar a grade curricular de cursos de formação inicial do professor de matemática 
das Universidades Públicas do Estado de São Paulo observando não só a existência de tal tema na grade, mas também a abordagem da Educação Financeira nesses cursos.

Neste trabalho buscamos analisar as grades curriculares dos cursos de licenciatura em matemática das Universidades Públicas do Estado de São Paulo, mais especificamente, se existem disciplinas cujo nome apresente Educação Financeira, Matemática Financeira ou algo similar nas grades curriculares. Caso existam, como tal disciplina é abordada nos cursos de formação inicial de professores de matemática.

Primeiramente, realizamos uma pesquisa na página do Ministério da Educação (eMEC) no ano de 2017 e buscamos as Universidades Públicas do Estado de São Paulo que possuem o curso de licenciatura em matemática, onde na página do e-MEC possui todas as instituições de ensino superior credenciadas no território brasileiro. Nesta pesquisa obtivemos quatorze cursos de formação de professores de matemática e para cada curso analisamos a grade curricular para verificar se existiam a disciplina de Educação Financeira e/ou Matemática Financeira, pois poderia ocorrer que em uma das duas disciplinas os tópicos de Educação Financeira fossem abordados. Não somente isso, também analisamos as ementas de outras disciplinas que poderiam aparecer temas relacionados à Educação Financeira.

Como resultado da pesquisa anteriormente descrita, obtivemos que o curso de licenciatura em matemática da Universidade Estadual Paulista Júlio de Mesquita Filho (UNESP) campus Bauru possui uma disciplina obrigatória de Educação Financeira em sua grade curricular. Os demais cursos encontrados não possuem uma disciplina específica de Educação Financeira em sua grade. Neste único curso que encontramos a disciplina de Educação Financeira, fomos investigar como tal tema é abordado em sala de aula através de uma pesquisa exploratória.

Essa pesquisa exploratória foi realizada em duas etapas, sendo, a primeira etapa realizada com o envio de um questionário online abordando questões específicas sobre a Educação Financeira e a Matemática Financeira. As questões tinham o objetivo de obter respostas sobre quais os temas eram abordados nas aulas da referida disciplina e se os assuntos tratados possibilitam ao futuro professor um melhor preparo para abordar o tema na sala de aula da educação básica. No ano de 2017, enviamos o questionário online para os alunos que se formaram no ano de 2016 no curso de licenciatura em matemática e também para os alunos que estavam cursando a disciplina de Educação Financeira (segundo semestre de 2017) da UNESP campus Bauru. Para o envio deste questionário online, entramos em 
contato com a coordenação do curso da UNESP campus Bauru em setembro do ano de 2017 e obtivemos uma lista com os endereços eletrônicos dos alunos matriculados na disciplina de Educação Financeira (segundo semestre de 2017) e dos alunos formados no ano de 2016 e através destas listas, enviamos o questionário duas vezes, a primeira vez no ano de 2017 e a segunda vez no ano 2018, com o objetivo de obtermos mais respostas.

A segunda etapa da nossa pesquisa consiste numa entrevista à distância, realizada no ano de 2019 com a docente que leciona atualmente e lecionava a disciplina de Educação Financeira no ano de 2017 para o curso de licenciatura em matemática da UNESP campus Bauru. As perguntas da entrevista tratavam de assuntos como sobre a disciplina de Educação Financeira, ementa da disciplina, os temas abordados em sala de aula e as atividades que eram realizadas com os alunos. Como na primeira etapa da pesquisa a docente se mostrou bastante receptiva, a realização da segunda etapa, a entrevista, foi de organização bastante fácil.

Com o envio do questionário online para os alunos da UNESP dos campi Bauru e Rio Claro, tivemos quatorze respostas no total, sendo oito respostas de alunos da UNESP de Rio Claro e seis respostas de alunos da UNESP campus Bauru. Todos os alunos da UNESP de Rio Claro confirmaram a não existência de disciplinas que abordam temas de Educação Financeira, e que o tema também não é abordado em nenhuma outra disciplina. Dentre os seis alunos da UNESP campus Bauru que responderam o questionário, dois alunos cursaram a disciplina de Educação Financeira e quatro alunos cursaram a disciplina de Matemática Financeira, pois somente a partir do ano de 2015 a disciplina de Educação Financeira passou a existir na grade curricular, anteriormente, a disciplina existente era de Matemática Financeira.

Analisamos a ementa da disciplina de Educação Financeira desde o ano de 2015 e pudemos observar a possiblidade da contextualização da Matemática Financeira com atividades voltadas para os ensinos fundamental e médio. Diante das respostas dos alunos que cursaram a disciplina de Educação Financeira, todos responderam que aprenderam basicamente fórmulas de Matemática Financeira, mesmo os alunos respondendo que tiveram somente fórmulas, acreditamos que eles se recordaram apenas das fórmulas ao responder o questionário, pois na ementa da tal disciplina consta a abordagem da Matemática Financeira relacionada com atividades voltadas para o ensino básico.

Através da entrevista realizada com a docente, pudemos obter mais detalhes de como surgiu a disciplina de Educação Financeira na grade curricular do curso de licenciatura em 
matemática na UNESP campus Bauru. De acordo com o relato da entrevistada, antes do ano de 2015 a disciplina de Matemática Financeira não era lecionada por professores do departamento da licenciatura em matemática, sendo assim, os conteúdos ministrados em sala de aula não necessariamente tinham uma contextualização com atividades voltadas à educação. Após o ano de 2015 a disciplina passou a ser lecionada por professores do departamento de licenciatura em matemática, logo a disciplina sofreu alteração na ementa e passou a contemplar a contextualização com atividades dos ensinos fundamental e médio, porém com o nome de Educação Financeira. Ainda, através dos trechos obtidos pela entrevista, os temas são abordados em sala de aula com contextualização de situações do dia a dia, não é ministrada somente conteúdos técnicos sem contextualização alguma.

Dado que a disciplina de Educação Financeira foi inserida recentemente na grade curricular do curso e que, a ementa tem sofrido alterações desde o ano de 2015, pudemos destacar uma preocupação da docente ao abordar o tema em sala de aula. Durante a entrevista, a professora deixa claro que sempre busca contextualizar a Matemática Financeira com situações cotidianas, e que mesmo diante das respostas dos alunos de que foi abordado somente fórmulas durante a disciplina, acreditamos que os alunos se recordaram apenas das fórmulas matemáticas, pois tanto no relato da professora quanto na ementa da disciplina existe a abordagem da Matemática Financeira com atividades voltadas para a educação, além de ser uma disciplina recentemente inserida na grade curricular. 


\section{EDUCAÇÃO FINANCEIRA}

No Brasil, em dezembro de 1996 foi aprovada a Lei de Diretrizes e Bases da Educação (LDB) sob o número 9.394/96 que institui que a educação escolar é dever da família e do Estado, ou seja, reafirmando o direito à educação já garantido pela Constituição Federal de 1988. Além da garantia à educação, a LDB institui que a educação escolar deve se vincular ao mundo do trabalho e à prática social.

Art. 1

$\S 2$ A educação escolar deverá vincular-se ao mundo do trabalho e à prática social. (BRASIL, 1996)

Art. 2

A educação, dever da família e do Estado, inspirada nos princípios de liberdade e nos ideais de solidariedade humana, tem por finalidade o pleno desenvolvimento do educando, seu preparo para o exercício da cidadania e sua qualificação para o trabalho. (BRASIL, 1996)

O Brasil estava em um cenário de grave crise econômica no ano de 2016 com um recuo do Produto Interno Bruto (PIB), sendo assim, para tornar o indivíduo com mais noções de Educação Financeira e ter boas relações de consumo, como consequência, surgiu em 2016 o tema de consumo e Educação Financeira na LDB.

Primeiramente, em um cenário de grave crise econômica atualmente
verificado no Brasil, mostra-se fundamental que o indivíduo, desde as fases
iniciais da sua caminhada estudantil, possa ter acesso a noções de Educação
Financeira e como sucedem as relações de consumo, com vistas a incutir
em seu comportamento a responsabilidade no trato com o dinheiro e com
outros valores. Em uma segunda medida, a importância do tema revela-se
nas ações cotidianas da sociedade. As relações de consumo, operações
financeiras e manuseio da moeda são realizadas diariamente inúmeras
vezes, das mais diversas formas e com os mais variados propósitos. Nesse
contexto, exige-se da maioria dos indivíduos certa prudência, uma reflexão
sobre a melhor destinação que será dada às economias obtidas. (BRASIL,
2016)

Nesse projeto de Lei em 2016 foi acrescido o § 10 ao Art. 26 da LDB, que estabelece as diretrizes e bases da educação nacional, para incluir consumo e Educação Financeira como temas integradores dos componentes curriculares nos diversos níveis da educação básica. 
Art. 26

$\S 10$ Consumo e Educação Financeira serão temas integradores dos componentes curriculares nos diversos níveis da educação básica. (BRASIL, 2016)

A inclusão explícita do tema da Educação Financeira na LDB pode favorecer uma sociedade mais consciente com relação à importância deste tema na educação.

Além da inclusão da Educação Financeira na LDB, fomos investigar como tal tema é abordado em outras resoluções e legislações que tratam da educação básica brasileira, como a Base Nacional Comum Curricular (BNCC), os Parâmetros Curriculares Nacionais de Matemática (PCNs de Matemática) e as Diretrizes Curriculares Nacionais (DCNs).

Em ordem cronológica inversa, temos primeiro a Base Nacional Comum Curricular (BNCC). A BNCC é um documento que foi finalizado no ano de 2018, onde define o conjunto de aprendizagens a serem trabalhadas em todas as escolas brasileiras, seja escola pública ou privada, desde o ensino infantil até o ensino médio.

Na BNCC, a educação infantil é dividida em grupos por faixa etária: bebês (zero a um ano e seis meses), crianças bem pequenas (um ano e sete meses a três anos e onze meses) e crianças pequenas (quatro anos a cinco anos e onze meses). Para cada faixa etária existem os objetivos de aprendizagem detalhados.

O ensino fundamental é organizado em cinco áreas do conhecimento: linguagens, matemática, ciências da natureza, ciências humanas e ensino religioso. Essas cinco áreas possuem as suas competências específicas e são abordadas ao longo dos nove anos. Já o ensino médio, este é composto por três anos e está organizado em quatro áreas de conhecimento: linguagens e suas tecnologias, matemática e suas tecnologias, ciências da natureza e suas tecnologias e ciências humanas e sociais aplicadas.

\footnotetext{
A Base Nacional Comum Curricular (BNCC) é um documento de caráter normativo que define o conjunto orgânico e progressivo de aprendizagens essenciais que todos os alunos devem desenvolver ao longo das etapas e modalidades da Educação Básica, de modo a que tenham assegurados seus direitos de aprendizagem e desenvolvimento, em conformidade com o que preceitua o Plano Nacional de Educação (PNE). (BNCC, 2018)
}

As aprendizagens essenciais definidas na BNCC ao longo da educação básica, devem proporcionar aos alunos à desenvolverem as dez competências gerais conforme descritas no próprio texto: 
Na BNCC, competência é definida como a mobilização de conhecimentos (conceitos e procedimentos), habilidades (práticas, cognitivas e socioemocionais), atitudes e valores para resolver demandas complexas da vida cotidiana, do pleno exercício da cidadania e do mundo do trabalho. (BNCC, 2018)

A Educação Financeira é descrita na BNCC como um tema contemporâneo que deve ser tratado de maneira transversal nas escolas da educação básica.

Por fim, cabe aos sistemas e redes de ensino, assim como às escolas, em suas respectivas esferas de autonomia e competência, incorporar aos currículos e às propostas pedagógicas a abordagem de temas contemporâneos que afetam a vida humana em escala local, regional e global, preferencialmente de forma transversal e integradora. Entre esses temas, destacam-se: direitos da criança e do adolescente (Lei $\mathrm{n}^{\mathbf{o}}$ 8.069/199016), educação para o trânsito (Lei n ${ }^{0}$ 9.503/199717), educação ambiental (Lei no 9.795/1999, Parecer CNE/CP n 14/2012 e Resolução $\mathrm{CNE} / \mathrm{CP} \mathrm{n}^{\mathrm{o}}$ 2/201218), educação alimentar e nutricional (Lei $\mathrm{n}^{\circ}$ 11.947/200919), processo de envelhecimento, respeito e valorização do idoso (Lei $\left.n^{\circ} 10.741 / 200320\right)$, educação em direitos humanos (Decreto $n^{\circ}$ 7.037/2009, Parecer CNE/CP no 8/2012 e Resolução CNE/CP n ${ }^{\circ}$ $1 / 201221$ ), educação das relações étnico-raciais e ensino de história e cultura afro-brasileira, africana e indígena (Leis $\mathrm{n}^{\circ} 10.639 / 2003$ e 11.645/2008, Parecer CNE/CP n $3 / 2004$ e Resolução CNE/CP no 1/200422), bem como saúde, vida familiar e social, educação para o consumo, Educação Financeira e fiscal, trabalho, ciência e tecnologia e diversidade cultural (Parecer CNE/CEB n ${ }^{\circ}$ 11/2010 e Resolução CNE/CEB $\mathrm{n}^{\mathrm{o}}$ 7/201023). (BNCC, 2018)

Os conteúdos que constam na BNCC são organizados em unidades temáticas correlacionadas. Para a Matemática do ensino fundamental existem as temáticas: Números, Álgebra, Geometria, Grandezas e Medidas e Probabilidade e Estatística. Analisando o documento da BNCC, pudemos verificar que o tema de Educação Financeira consta na temática de Números, sendo essa temática definida como:

\footnotetext{
A unidade temática Números tem como finalidade desenvolver o pensamento numérico, que implica o conhecimento de maneiras de quantificar atributos de objetos e de julgar e interpretar argumentos baseados em quantidades. (BNCC, 2018)
}

Em Números, o tema de Educação Financeira deve ser tratado segundo as suas especificidades de forma contextualizada, preferencialmente relacionando-a com outra disciplina. 


\begin{abstract}
Outro aspecto a ser considerado nessa unidade temática é o estudo de conceitos básicos de economia e finanças, visando à Educação Financeira dos alunos. Assim, podem ser discutidos assuntos como taxas de juros, inflação, aplicações financeiras (rentabilidade e liquidez de um investimento) e impostos. Essa unidade temática favorece um estudo interdisciplinar envolvendo as dimensões culturais, sociais, políticas e psicológicas, além da econômica, sobre as questões do consumo, trabalho e dinheiro. (BNCC, 2018)
\end{abstract}

Assuntos relacionado à Educação Financeira aparecem na temática de Números no $5^{\circ}$ Ano, $6^{\circ}$ Ano, $7^{\circ}$ Ano e $9^{\circ}$ Ano. Em todas essas séries, em resumo, aparece menção explícita para se trabalhar o cálculo de porcentagens contextualizando-o com temas de taxas de juros, inflação, aplicação financeira e impostos. Este tema também pode ser relacionado com outras disciplinas, como por exemplo, a disciplina de História visando o estudo da inflação e sistemas econômicos ao longo do tempo.

Já para o ensino médio, a área de matemática e suas tecnologias estabelecida pela BNCC propõe a ampliação, a consolidação e o aprofundamento dos aprendizados obtidos no ensino fundamental. No caso específico de Educação Financeira, o tema é tratado majoritariamente em Números e Álgebra, pois não há uma divisão específica entre temáticas, como no ensino fundamental.

Contudo, de acordo com a BNCC, em específico da área de matemática, o tema de Educação Financeira deve ser abordado no ensino fundamental de diversas maneiras pelos professores, como por exemplo, a abordagem de representações percentuais contextualizados com consumo.

Temas que são abordados pelos professores dentro da sala de aula da educação básica geralmente apareceram de forma aprofundada e embasada durante a formação inicial destes professores, como por exemplo, geometria e o seu ensino, sendo assim, o tema de Educação Financeira também poderia ser abordado, de modo a propiciar aos futuros professores maior embasamento a fim de proporcionar melhores discussões sobre esse assunto na educação básica.

[...] cresce a importância da Educação Financeira e da compreensão do sistema monetário contemporâneo nacional e mundial, imprescindíveis para uma inserção crítica e consciente no mundo atual. (BNCC, 2018)

Anteriormente à BNCC, grande parte do que se fazia na educação básica era norteado pelos Parâmetros Curriculares Nacionais, em nosso caso em específico, os de Matemática 
(PCNs Matemática). Os Parâmetros Curriculares Nacionais são diretrizes promulgadas no ano de 1999 com o objetivo de orientar os professores através da normatização de cada disciplina para o ensino fundamental e ensino médio. Essas diretrizes são publicadas pelo Governo Federal e não são obrigatórias por lei, já que são parâmetros norteadores e não componentes obrigatórios.

Os Parâmetros Curriculares Nacionais - PCN — são referências para os Ensinos Fundamental e Médio de todo o país. O objetivo dos PCN é garantir a todas as crianças e jovens brasileiros, mesmo em locais com condições socioeconômicas desfavoráveis, o direito de usufruir do conjunto de conhecimentos reconhecidos como necessários para $\mathrm{o}$ exercício da cidadania. Não possuem caráter de obrigatoriedade e, portanto, pressupõe-se que serão adaptados às peculiaridades locais. (BRASIL, 1998)

Ao analisar os PCNs específicos de Matemática percebemos que não consta a Educação Financeira explicitamente e com essas palavras, mas possibilita a inserção do tema no currículo através dos denominados Temas Transversais ao abordar temas relacionados à educação do consumidor.

Temas relacionados à educação do consumidor, por exemplo, são contextos privilegiados para o desenvolvimento de conteúdos relativos a medida, porcentagem, sistema monetário, e, desse modo, podem merecer especial atenção no planejamento de Matemática. (BRASIL, 1998 p. 5)

Um outro normativo da educação brasileira que também fomos investigar são as Diretrizes Curriculares Nacionais (DCNs). As DCNs são normas obrigatórias para a educação que orientam no planejamento curricular das escolas e foram criadas anteriormente aos PCNs. Analisamos as DCNs e neste documento não consta nenhuma abordagem sobre o tema de Educação Financeira nos currículos.

Diante da abordagem do tema de Educação Financeira na educação brasileira, também verificamos que o tema de Educação Financeira foi abordado mundialmente através da Organização para Cooperação e Desenvolvimento Econômico (OCDE), que se autodescreve como:

A Organização para Cooperação e Desenvolvimento Econômico (OCDE) é uma organização internacional que trabalha para construir melhores políticas para uma vida melhor. Nosso objetivo é moldar políticas que promovam a prosperidade, a igualdade, a oportunidade e o bem-estar para todos. (OCDE) 
A OCDE é composta atualmente por 36 países membros em todo o mundo com o objetivo de promover políticas para o desenvolvimento econômico e bem-estar social das pessoas. Os países que compõem a OCDE são: Austrália, Áustria, Bélgica, Canadá, Chile, República Checa, Dinamarca, Estónia, Finlândia, França, Alemanha, Grécia, Hungria, Islândia, Irlanda, Israel, Itália, Japão, Letônia, Lituânia, Luxemburgo, México, Países Baixos, Nova Zelândia, Noruega, Polónia, Portugal, Eslováquia, Eslovênia, Coreia do Sul, Espanha, Suécia, Suíça, Turquia, Reino Unido e Estados Unidos.

A Organização para a Cooperação e Desenvolvimento Econômico OCDE, com sede em Paris, França, é uma organização internacional composta por 36 países membros, que reúne as economias mais avançadas do mundo, bem como alguns países emergentes como a Coreia do Sul, o Chile, o México e a Turquia. (OCDE)

O Brasil por sua vez está atualmente classificado como parceiro-chave e participa diretamente e ativamente nos trabalhos, discussões e pesquisas realizadas pela Organização.

O relacionamento entre a Organização e o Brasil se aprofundou a partir de 1999, quando o Conselho da OCDE decidiu criar um programa direcionado ao Brasil. Em maio de 2007, o Conselho Ministerial da OCDE decidiu "fortalecer a cooperação da OCDE com o Brasil, China, Índia, Indonésia e África do Sul" por meio do programa de enhanced engagement, tornando possível a adesão desses países à OCDE. Em 2012, esses cinco países passaram a ser considerados key partners (parceiros-chave) na Organização. (OCDE)

Questões sócio econômicas que afetam diretamente a vida dos cidadãos, como por exemplo, o quanto as pessoas pagam de impostos e temas de previdência social são discutidas na OCDE e a partir das discussões são elaboradas políticas com o objetivo de melhorar a qualidade de vida das pessoas. O objetivo central é de que todos os países, juntos, identifiquem problemas, discutam ou observem exemplos de outros para que por fim produzam políticas passiveis de aplicação com a intenção de resolver ou reduzir problemas latentes.

Juntamente com governos, formuladores de políticas e cidadãos, trabalhamos no estabelecimento de normas internacionais e na busca de soluções baseadas em evidências para uma série de desafios sociais, econômicos e ambientais. Desde melhorar o desempenho econômico e criar empregos até promover forte educação e combater a evasão fiscal internacional, fornecemos um fórum e um centro de conhecimento exclusivos para dados e análises, troca de experiências, compartilhamento 
de práticas recomendadas e aconselhamento sobre políticas públicas e definição de padrões globais. (OCDE)

Dentre as políticas de desenvolvimento estabelecidas pela OCDE, o Brasil participou de uma que tratava da educação financeira do cidadão sobre a Educação Financeira.

\begin{abstract}
A Educação Financeira tornou-se um complemento importante da conduta do mercado e da regulamentação prudencial ao melhorar os comportamentos financeiros dos indivíduos. O governo brasileiro tem se empenhado em informar a crescente classe média sobre como economizar e investir com sabedoria, ajudando as famílias mais pobres a entender e usar os serviços financeiros básicos. (OCDE)
\end{abstract}

Após análise de que a Educação Financeira está presente não só nos normativos relativos a educação básica brasileira, mas também em órgãos internacionais, como a OCDE, gostaríamos de aproveitar a definição de Educação Financeira que aparece no documento "Recomendações sobre os princípios e boas práticas para a Educação Financeira" publicado pela OCDE em 2005, para discutir um pouco mais a fundo sobre o assunto.

\begin{abstract}
Educação Financeira é o processo mediante o qual os indivíduos e as sociedades melhoram a sua compreensão em relação aos conceitos e produtos financeiros, de maneira que, com informação, formação e orientação, possam desenvolver os valores e as competências necessários para se tornarem mais conscientes das oportunidades e riscos neles envolvidos e, então, poderem fazer escolhas bem informadas, saber onde procurar ajuda e adotar outras ações que melhorem o seu bem-estar. Assim, podem contribuir de modo mais consistente para a formação de indivíduos e sociedades responsáveis, comprometidos com o futuro. (OCDE, 2005)
\end{abstract}

Dentre as diversas, mas não excludentes, definições de Educação Financeira, temos outras como:

[...] a capacidade de fazer julgamentos inteligentes e decisões eficazes em relação ao uso e gestão do dinheiro. (GALLERY, 2011)

[...] um processo de transmissão de conhecimento que permite o desenvolvimento de habilidades nos indivíduos, para que eles possam tomar decisões fundamentais e seguras, melhorando o gerenciamento de suas finanças pessoais. (SAVOIA, SAITO E SANTANTA, 2007)

Já de acordo com o autor LELIS (2006), a Educação Financeira é importante, pois abrange informações de como aumentar a renda, reduzir despesas e gerenciar fundos, ou seja, uma ferramenta utilizada para fazer uma gestão com eficácia do próprio dinheiro. 
Diante de várias propostas estabelecidas para a inclusão da Educação Financeira na educação dos alunos, seja através da inclusão explícita estabelecida na última alteração da LDB e na BNCC ou até mesmo pela inclusão implícita estabelecida pelos PCNs, temos também a orientação de políticas de órgãos internacionais como a OCDE de que a "Educação Financeira deveria começar o mais cedo possível e ser ensinada nas escolas”, OCDE (2005).

Seguindo tendências mundiais, no Brasil com o objetivo de proporcionar aos cidadãos ações que os ajudem a tomar decisões financeira, além da inclusão do tema em documentos normativos da educação básica, foi criada a Estratégia Nacional de Educação Financeira (ENEF) que utilizou como base o conceito estabelecido pela OCDE, visto que o Brasil é um dos parceiros-chave.

O objetivo da ENEF, criada através do Decreto Federal 7.397/2010, é contribuir para o fortalecimento da cidadania ao fornecer e apoiar ações que ajudem a população a tomar decisões financeiras mais autônomas e conscientes. (BRASIL/ENEF, 2011)

A Estratégia Nacional de Educação Financeira (ENEF) foi definida como política de Estado a partir do Decreto Federal 7.397 no ano de 2010 com o objetivo de apoiar e fornecer ações que sirvam como auxílio para a população poder tomar decisões financeiras mais conscientes e independentes. A ENEF se estabeleceu com a finalidade de "promover a Educação Financeira e previdenciária e contribuir para o fortalecimento da cidadania, a eficiência da solidez do sistema financeiro nacional e a tomada de decisões conscientes por parte dos consumidores", ENEF (2011).

Atualmente sete órgãos e entidades de governos e seis organizações da sociedade civil, juntos integram o Comitê Nacional de Educação Financeira (CONEF). Os órgãos do governo são: Banco Central do Brasil, Comissão de Valores Mobiliários, Superintendência Nacional de Previdência Complementar, Superintendências de Seguros Privados, Ministério da Justiça e Cidadania, Ministério da Educação e Ministérios da Fazenda. Os representantes da sociedade civil são: Anbima, Bolsa de Valores (B3), CNseg, Febraban, Sebrae, Consed.

Mesmo não tendo sido criada com o objetivo específico de tratar da Educação Financeira na educação básica, a ENEF, que tem apenas uma entidade da educação membro do CONEF, publicou o Programa de Educação Financeira nas Escolas com um projeto pedagógico e livros para os níveis do ensino fundamental e ensino médio. Estes livros buscam oferecer atividades educativas para o aluno e para o professor com temas sobre Educação Financeira relacionados com o cotidiano. O modelo do projeto pedagógico e o 
conteúdo dos livros foram utilizados como base um documento elaborado pelos: Ministério da Educação (MEC), União Nacional dos Dirigentes Municipais de Educação (UNDIME) e Conselho Nacional de Secretários de Educação (CONSED).

\footnotetext{
Tanto o modelo pedagógico quanto os conteúdos financeiros possibilitam ao aluno se colocar como protagonista de sua história de vida, dando a ele condições de planejar e fazer acontecer o futuro que deseja para si, em conexão com o grupo familiar e social a que pertence. (ASSOCIAÇÃO DE EDUCAÇÃO FINANCEIRA DO BRASIL)
}

Embora existam diversos programas sobre Educação Financeira, queremos destacar aqui o projeto piloto no Brasil que se iniciou em agosto de 2010 até dezembro de 2011 realizado pelo Banco Mundial, implementando o projeto de Educação Financeira nas Escolas. O projeto foi aplicado em um total de 900 escolas em seis estados brasileiros: São Paulo, Rio de Janeiro, Ceará, Tocantins, Minas Gerais e o Distrito Federal. Além da aplicação do projeto, foi realizado também um workshop de Educação Financeira com os alunos e responsáveis dos alunos com o objetivo de reforçar os conteúdos ensinados em sala de aula e consequentemente medir o impacto do projeto. O objetivo principal deste projeto piloto foi de avaliar o impacto da Educação Financeira sobre o conhecimento dos alunos.

A avaliação do projeto piloto ocorreu através da aplicação de questionários para os alunos, para os professores e para os responsáveis dos alunos antes e após a aplicação do projeto. Os resultados obtidos através do programa sugeriram que houve um aumento no conhecimento financeiro dos alunos e que com o programa, os alunos ficaram mais propensos a poupar e administrar as suas despesas.

\footnotetext{
Nossos resultados sugerem que o programa de Educação Financeira nas escolas aumentou o conhecimento financeiro dos alunos e melhorou suas atitudes financeiras. $O$ programa também levou a mudanças no comportamento financeiro dos alunos. Especificamente, devido ao programa, os alunos estão mais propensos a poupar e administrar suas despesas, conversar com seus pais sobre questões financeiras e ajudar a organizar o orçamento familiar. Esses efeitos se mantiveram no curto e no longo prazo, o que permite afirmar a sustentabilidade e longevidade do treinamento que os alunos receberam. (BANCO MUNDIAL)
}

Como exemplo de como era a Educação Financeira do cidadão brasileiro anteriormente a ENEF, destacamos a pesquisa realizada pela Bolsa de Mercadorias e Futuros (BMF) com a Data Popular no ano de 2008 com o objetivo de avaliar o grau de Educação Financeira da população brasileira. Foram entrevistados 1809 pessoas de diferentes rendas 
e graus de educação nas capitais Porto Alegre, São Paulo, Rio de Janeiro, Brasília, Salvador e Recife. Temas como o orçamento doméstico, hábitos de consumo, poupança, investimento e outros foram abordados na pesquisa.

O processo da pesquisa foi feito em etapas devido ao tamanho da população de 1809 pessoas através de entrevistas qualitativas e quantitativas. A primeira etapa desta pesquisa (qualitativa) tinha crianças de 11 a 15 anos, adultos de 18 a 45 anos e idosos com mais de 60 anos, contendo pessoas com renda mensal entre $\mathrm{R} \$ 700,00$ a $\mathrm{R} \$ 3500,00$ e com ensino médio incompleto. Esses integrantes foram dispostos em oito grupos de discussão, sendo quatro grupos em São Paulo e quatro grupos no Recife.

Já a segunda etapa com uma pesquisa quantitativa, tinha homens e mulheres com renda mensal variando de $\mathrm{R} \$ 570,00$ a $\mathrm{R} \$ 5701,00$ entre 20 e 70 anos e de várias classes sociais (A, B, C e D) e nas seis cidades citadas.

$\mathrm{Na}$ pesquisa havia questões sobre o orçamento familiar, hábitos de gastos, conhecimento de produtos financeiros, crédito, poupança e outros. Os resultados obtidos com a pesquisa qualitativa demonstraram um baixo nível de Educação Financeira da população brasileira.

Temos que "A conclusão principal da pesquisa, após a realização das entrevistas, é que o nível de Educação Financeira da população brasileira é ainda baixo”, DATA POPULAR.

Ainda nesta pesquisa, lembrando que esta é anterior a ENEF, existe a defesa da inclusão da Educação Financeira nas escolas, pois acredita-se que a Educação Financeira traga um benefício para a sociedade estabelecendo cidadãos críticos para a sociedade.

Com a introdução da Educação Financeira nas escolas, espera-se que os indivíduos e as sociedades tenham condições de moldar seu próprio destino de modo mais confiante e seguro se tornando agentes de seu próprio desenvolvimento. (DATA POPULAR)

A importância de se abordar temas de Educação Financeira em escolas, conforme estabelecido pela OCDE e também pela pesquisa citada anteriormente, tem se destacado, e de acordo com a HOFFMAN e MORO (2010), o alto nível de jovens inadimplentes pode ser devido ao baixo nível de letramento financeiro.

Dados da Pesquisa de Endividamento e Inadimplência do Consumidor, realizada em julho de 2010 pelo Serasa (2010), apontam que 60\% dos jovens paulistas entre 18 e 34 anos são consumidores inadimplentes, o que pode ser considerado indício do baixo nível de letramento financeiro. (HOFFMAN e MORO, 2010) 
Não somente no Brasil, mas outros países também realizaram pesquisas sobre o nível de Educação Financeira da população. Foi realizada uma entrevista com 150 mil adultos (pessoas acima de 15 anos) em mais de 140 países com perguntas sobre quatro conceitos financeiros básicos: diversificação de risco, inflação, habilidade numérica e juros compostos. Como resultado, a pesquisa revelou que dois em cada três adultos são analfabetos financeiros variando entre grupos e países. Este resultado foi publicado em 2016 pela Standard \& Poor's Global Financial Literacy Survey.

The S\&P Global FinLit Survey findings are sobering. Worldwide, only 1in-3 adults are financially literate. Not only is financial illiteracy widespread, but there are big variations among countries and groups. (STANDARD AND POOR'S)

Nesta pesquisa feita pela Standard \& Poor's Global Financial Literacy Survey, no Brasil, em específico, somente $35 \%$ das pessoas entrevistadas acertaram questões relacionadas a pelo menos três dos quatro conceitos analisados.

Diante de algumas pesquisas expostas neste trabalho, onde demonstram que a população brasileira possui um baixo nível de Educação Financeira, verificamos em BRASIL (2010) podemos encontrar trechos que citam que as pessoas não se planejam financeiramente para a aposentadoria e nem para os gastos no longo prazo.

[...] as pessoas não planejam seus gastos no longo prazo, demoram para se preparar financeiramente para a aposentadoria, não estão completamente cientes dos riscos e dos instrumentos para a sua proteção, têm dificuldades em tomar decisões a respeito de empréstimos e investimentos, e são vulneráveis a fraudes. (BRASIL, 2010, p. 2)

No Brasil, por sua vez, são poucas pessoas que realizam um planejamento financeiro, o que nos leva a um ciclo vicioso de falta de ensinamento devido a falta de prática e a não prática devido ao não conhecimento, pois "No Brasil, são poucas as pessoas que têm o hábito de fazer planejamento financeiro, como não se pratica também não se ensina", CAPRONI.

A Educação Financeira tem a sua devida importância em sala de aula, mas também um papel importante que ultrapassa os ambientes escolares, pois: 
[...] a Educação Financeira se configura como um instrumento capaz de promover o desenvolvimento econômico, pois a qualidade das decisões financeiras dos indivíduos influencia toda a economia, tendo em vista que está intimamente ligada a problemas como os níveis de endividamento e de inadimplência das pessoas e a capacidade de investimento dos países. (CAMPOS, TEIXEIRA, COUTINHO, 2015, p. 557)

A possibilidade de as sociedades melhorarem a sua compreensão com relação aos conceitos e produtos financeiros pode ser obtida através do ensino da Educação Financeira, segundo a ENEF “A Educação Financeira possibilita que os indivíduos e as sociedades melhorem sua compreensão em relação aos conceitos e produtos financeiros”, BRASIL (2010).

Através da Educação Financeira em sala de aula, podemos por exemplo, educar um cidadão consumidor e até proporcionar uma melhor compreensão conceitual dos produtos financeiros, de modo que, com informação e orientação, os cidadãos possam obter um equilíbrio financeiro e consequentemente até influenciar a economia como um todo.

Para que educar o consumidor? Educar o consumidor é torná-lo equilibrado, livre e independente para usufruir corretamente de seu salário e de sua reserva econômica. (D’AQUINO, 2008, p. 29)

[...] entendemos que a sociedade do século XXI não pode prescindir de discutir uma Educação Financeira, bem como significados em torno de ideias, que se embasam em práticas conscientes de consumo. (KISTEMANN JR., 2011, p.30)

Sendo assim, o tema da Educação Financeira é um tema muito importante podendo impactar pessoas, sociedades e inclusive a economia de um país, pois mudanças econômicas em um país pode impactar a decisão financeira de uma sociedade.

De acordo com CAMPOS, TEIXEIRA, COUTINHO (2015), o tema de Educação Financeira pode ser abordado no ambiente escolar com vários temas, como:

- Compreender a influência dos juros no cotidiano;

- Conhecer o mercado financeiro para obter mais rendimentos;

- Consumir produtos bancários com mais consciência;

- Ter uma boa gestão pessoal do dinheiro;

- Saber aproveitar oportunidades de financiamentos;

- Ter um consumo consciente, evitando o consumo desenfreado; 
A importância da formação do professor de matemática para o ensino da Educação Financeira é ressaltada pelos autores CAMPOS, TEIXEIRA e COUTINHO (2015), pois eles defendem que haja nos cursos de licenciatura em matemática subsídios que proporcionem aos professores conhecimentos significativos. Ainda, segundo os pesquisadores, a formação dos professores precisa ser melhorada tecnicamente para que possam conectar a Matemática Financeira com a Educação Financeira em sala de aula, pois "se faz necessário melhorar a formação dos professores que lecionam Matemática Financeira, objetivando conectar essa disciplina à Educação Financeira", CAMPOS, TEIXEIRA e COUTINHO (2015).

A educação tem um papel muito importante na sociedade, em (SKOVSMOSE, 2001, p.87) enfatiza que o preparo dos alunos para a participação na sociedade é uma preocupação constante da educação e que a educação tem por objetivo preparar os alunos para uma sociedade crítica. A problematização de situações cotidianas com o conteúdo ensinado em sala de aula é responsabilidade dos professores, pois de acordo com KISTEMANN, ALMEIDA E NETO (2017) este destaca que o papel do professor é utilizar a teoria aprendida ao longo da sua formação para solucionar situações problemas do dia a dia que os alunos estão inseridos, pois existem diversos conteúdos que são ensinados na sala de aula e que não são utilizados para solucionar problemas reais. Sendo assim é necessário o professor abordar essa relação da realidade com a teoria de modo que os estudantes possam ver a real necessidade do que estão aprendendo em sala de aula.

Contextualizar temas técnicos com o cotidiano dos alunos é um desafio constante para os professores, é necessário que o professor domine o assunto e saiba relacioná-lo ao dia a dia dos estudantes, pois o conteúdo ensinado em sala de aula deve estar relacionado com problemas reais e não somente com os conteúdos descritos nos livros didáticos, por exemplo.

A formação dos professores deve possibilitar a superação de simples reprodução dos modelos apresentados no livro didático. Na maioria das vezes, os conteúdos apenas são transferidos sem nenhuma contextualização não ocorrendo a aprendizagem significativa. (PEPPE, 2015, p.3)

A realidade não pode servir sempre como uma referência de conteúdo para ser ensinado em sala de aula, mas a teoria e a realidade precisam estar conectadas de modo a fazer sentido para os alunos. Os exercícios utilizados para a Educação Financeira devem ser selecionados de maneira que o conteúdo ensinado também seja relacionado com o cotidiano vivenciado pelos alunos, porque existem problemas da vida real que podem ser 
enriquecedores para o processo de aprendizagem do aluno, dando mais significado real para o que se está aprendendo.

A contextualização é importante em sala de aula para que o professor possa aproximar os conteúdos aprendidos durante a sua formação com a realidade dos alunos.

Contudo, o ensino de conteúdos de Matemática Financeira dentro da disciplina de Matemática em si não basta para cumprir o papel de formar cidadãos e promover a Educação Financeira se ele não for contextualizado em situações reais ou realísticas, próximas ao cotidiano do educando. (CAMPOS, TEIXEIRA, COUTINHO, 2005, p.564)

Para que o professor de matemática possa trabalhar a Educação Financeira com seus alunos é necessário que este professor esteja preparado e seguro do que vai ensinar e para isso espera-se que tenha discutido tais assuntos durante a sua formação.

\footnotetext{
A Educação Financeira, tão importante para o cidadão, só pode ser ensinada nas escolas por meio de um corpo docente devidamente letrado. Isso implica em que o professor conheça e domine os conceitos de Matemática Financeira, além de conhecer e aplicar em suas aulas os pressupostos da Matemática Crítica. (TEIXEIRA, COUTINHO, 2015, p.19)
}

O tema de Educação Financeira não é somente discutido no Brasil, mas é um tema discutido mundialmente. Com base na ideia de que a discussão sobre Educação Financeira está sendo abordada diretamente na LDB, na BNCC e que nos PCNs constam a possiblidade de inserir o tema, é desejável que o tema seja abordado durante a formação inicial do professor de matemática para o que o mesmo possa melhor abordá-lo dentro de sala de aula. A capacitação teórica dos professores é fundamental para que o ensino de Educação Financeira seja ensinado em diversos níveis escolares, assim como sugerem os autores TEIXEIRA, COUTINHO (2015) quando destacam a necessidade de um corpo docente devidamente letrado para se abordar Educação Financeira em suas aulas.

Contudo, buscamos contextualizar o tema de Educação Financeira e a sua inserção na educação brasileira e que o devido tema ultrapassa a sala de aula, podendo causar um impacto na sociedade como um todo, pois é um tema discutido não somente no Brasil, mas em diversos outros países. Expomos pesquisas, projetos relacionados e os seus devidos resultados que foram relevantes, sendo assim provocando uma discussão da necessidade de abordar o ensino de Educação Financeira nas escolas brasileiras e consequentemente o preparo do professor para a sala de aula. 
Embasados no que apresentamos até aqui passaremos agora à análise de como a Educação Financeira, seja ela disciplina ou assunto pertinente a alguma outra atividade formativa da graduação, está presente na formação inicial do professor de matemática dos cursos de licenciatura em matemática das Universidades Públicas do Estado de São Paulo, seja ela disciplina específica do curso de licenciatura, seja como conteúdo pertinente a alguma outra disciplina ou atividade prevista na grade curricular dos cursos de licenciatura em matemática das Universidades Públicas do Estado de São Paulo. 


\section{ANÁLISE DO CURRÍCULO DOS CURSOS DE LICENCIATURA EM MATEMÁTICA}

Uma pesquisa pode assumir papéis distintos dependendo do objetivo desejado, seja através da pesquisa criar uma visão geral de um determinado assunto ou de uma determinada condição, assim como novas ideias ou até mesmo conhecer em detalhes alguns fatos de uma determinada situação.

Pesquisa é um processo interminável, algo processual, considerando que,
na realidade, sempre vai existir o que descobrir, o importante é que os
resultados da pesquisa sejam divulgados para manter o progresso da ciência
com a geração de novos conhecimentos. Entretanto, a ciência não prescinde
de um método. (ARAÚJO, PAIVA, AUTRAN, RAMALHO, DUARTE,
2009)

A depender do método, podemos, por exemplo, classificar uma pesquisa em qualitativa e quantitativa conforme as definições abaixo:

a) Pesquisa Quantitativa: quando possibilita a quantificação tanto nos tipos de coleta de dados quanto no tratamento dos mesmos, através de técnicas estatísticas com o objetivo de analisar determinada (s) variável (is) de um problema.

b) Pesquisa Qualitativa: diferentemente da pesquisa quantitativa, a pesquisa qualitativa não utiliza nenhum instrumento estatístico como base para analisar o problema.

Através de uma pesquisa qualitativa, a geração de dados é obtida diretamente dos sujeitos que tiveram experiências com o problema (e/ou objeto) pesquisado.

Utilizamos neste trabalho a pesquisa qualitativa, dado que a escolha do tipo de pesquisa tem um papel importante na definição dos procedimentos de pesquisas, de acordo com Creswell (2010), na investigação qualitativa, as estratégias escolhidas têm enorme influência sobre os procedimentos. De acordo com Fraser e Gondim (2004), através de uma pesquisa qualitativa se conhece a perspectiva do outro para um determinado assunto e as 
suas motivações. Ao se utilizar uma pesquisa qualitativa, a mesma proporciona grandes significados, pois para um mesmo tema podemos obter resultados diferentes, seja a partir da visão de um referencial ou a partir de um método de pesquisa que não tenha sido contemplado em outras pesquisas.

Dentre as pesquisas qualitativas gostaríamos de destacar a exploratória que tem como objetivo detalhar mais um determinado problema, de acordo com o autor GIL (1999):

\footnotetext{
Estas pesquisas têm como objetivo proporcionar maior familiaridade com o problema, com vistas a torná-lo mais explícito ou a constituir hipóteses. Pode-se dizer que estas pesquisas têm como objetivo principal o aprimoramento de ideias ou a descoberta de intuições. Seu planejamento é, portanto, bastante flexível, de modo que possibilite a consideração dos mais variados aspectos relativos ao fato estudado. Na maioria dos casos, essas pesquisas envolvem: (a) levantamento bibliográfico; (b) entrevistas com pessoas que tiveram experiências práticas com o problema pesquisado;
}

A pesquisa exploratória proporciona uma investigação mais ampla com o objetivo de dar uma visão quando o tema escolhido é pouco explorado, ou seja, se trata de um aprofundamento do objeto de estudo.

Classificamos a nossa pesquisa como exploratória, pois se justifica pela necessidade de se investigar a disciplina de Educação Financeira oferecida nos cursos de licenciatura em matemática das Universidades Públicas do Estado de São Paulo.

A nossa pesquisa exploratória, iniciou-se com o levantamento das Universidades Públicas do Estado de São Paulo que possuem os cursos de licenciatura em matemática. De acordo com a grade curricular de cada curso, analisamos as que possuem a disciplina de Educação Financeira ou Matemática Financeira ou ainda aquelas que possuem em alguma de suas disciplinas tópicos relacionados a esse assunto.

A página do e-MEC foi criada em 2007 e possui as instituições de educação superior credenciadas no território brasileiro, sendo assim para tal análise consultamos a página http://emec.mec.gov.br no ano de 2017, ano de início de nosso trabalho.

Na seção da página do e-MEC destinada a consulta das instituições credenciadas, utilizamos os filtros: curso de graduação de licenciatura em matemática, gratuitos, na 
modalidade presencial e de instituições do Estado de São Paulo e como resultado dessa consulta obtivemos as seguintes Universidades e cursos:

a) Universidade de São Paulo - USP (campus Butantã)

b) Universidade de São Paulo - USP (campus São Carlos)

c) Universidade Estadual de Campinas - UNICAMP (campus Campinas)

d) Universidade Federal do ABC - UFABC (campus Santo André)

e) Universidade Federal de São Paulo - UNIFESP (campus Diadema)

f) Universidade Federal de São Carlos - UFSCar (campus São Carlos)

g) Universidade Federal de São Carlos - UFSCar (campus Sorocaba)

h) Universidade Estadual Paulista Júlio de Mesquita Filho - UNESP (campus Bauru)

i) Universidade Estadual Paulista Júlio de Mesquita Filho - UNESP (campus Guaratinguetá)

j) Universidade Estadual Paulista Júlio de Mesquita Filho - UNESP (campus Ilha Solteira)

k) Universidade Estadual Paulista Júlio de Mesquita Filho - UNESP (campus Presidente Prudente)

1) Universidade Estadual Paulista Júlio de Mesquita Filho - UNESP (campus São José do Rio Preto) 
m) Universidade Estadual Paulista Júlio de Mesquita Filho - UNESP (campus Rio Claro)

A grade curricular dos cursos de graduação pode ser composta por disciplinas obrigatórias e optativas (livres ou eletivas). A disciplina optativa eletiva é uma disciplina que o aluno tem que cursar em um conjunto pré-estabelecido de disciplinas. As disciplinas obrigatórias, como o próprio nome já diz, são disciplinas que necessariamente o estudante deve cursar para obter sua graduação, as disciplinas optativas livres são disciplinas em que o aluno pode escolher cursar ou não de acordo com a sua área de interesse ou mesmo interesses pessoais, já que as disciplinas optativas são aquelas em que o aluno necessariamente tem que cursar, mas ele pode optar por um dentre algumas possibilidades oferecidas pela instituição.

Ao analisarmos a grade curricular estabelecida e vigente dos cursos de cada uma dessas Universidades citadas anteriormente e em cada um dos campi, verificamos que somente a grade curricular da Universidade Estadual Paulista Júlio de Mesquita Filho (UNESP) campus Bauru prevê a disciplina de Educação Financeira como uma disciplina obrigatória para o curso de licenciatura em matemática. Nas demais Universidades não consta a disciplina de Educação Financeira nem como obrigatória e nem como optativa, mas em algumas existe a disciplina de Matemática Financeira como optativa ou como obrigatória e além disso também fomos investigar se existia uma outra disciplina, seja obrigatória ou optativa, abordando temas de Educação Financeira e/ou Matemática Financeira.

Na Universidade de São Paulo campus São Carlos, obtivemos dois cursos de graduação: o curso de licenciatura em matemática não possui nenhuma disciplina (optativa ou obrigatória) que aborde temas de Educação Financeira e/ou Matemática Financeira e o curso de ciências exatas com habilitação em matemática possui uma disciplina obrigatória que aborda temas de Matemática Financeira, já no campus Butantã verificamos que existe a disciplina de Matemática Financeira como uma disciplina optativa, porém a mesma é oferecida pela Faculdade de Economia e Administração.

$\mathrm{Na}$ Universidade de Campinas, campus Campinas, a disciplina de Matemática Financeira é optativa e é oferecida pelo Instituto de Matemática, Estatística e Computação.

A Universidade Federal do ABC, campus Santo André, oferece uma disciplina optativa denominada Engenharia Econômica. 
Na Universidade Federal de São Paulo, campus Diadema, o curso de ciências exatas com habilitação em matemática não possui nenhuma disciplina, seja obrigatória ou optativa, que aborde temas de Educação Financeira e/ou Matemática Financeira.

Na Universidade Federal de São Carlos, campi São Carlos e Sorocaba, ambos possuem a disciplina optativa de Matemática Financeira, porém a disciplina é oferecida para o curso de bacharelado em Ciências Econômicas e não é obrigatória para o curso de licenciatura.

A Universidade Estadual Paulista Júlio de Mesquita Filho, campi Ilha Solteira e São José do Rio Preto, possuem a disciplina obrigatória de Matemática Financeira e as mesmas são oferecidas para o curso de licenciatura em matemática. Já para o campus Presidente Prudente, existe a disciplina optativa de tópicos de Matemática Financeira e a mesma é oferecida para o curso de licenciatura em matemática. O campus de Rio Claro não possui nenhuma disciplina, seja obrigatória ou optativa, que aborde temas de Educação Financeira e/ou Matemática Financeira. No campus de Guaratinguetá, a disciplina de Matemática Financeira foi excluída da grade curricular a partir do ano de 2015 e não encontramos outra disciplina que aborde tais temas.

Dentre os quatorze cursos, temos: quatro cursos que não possuem nenhuma disciplina, optativa ou obrigatória, que aborda temas de Educação Financeira e/ou Matemática Financeira; quatro cursos que possuem uma disciplina optativa que aborda temas de Matemática Financeira, porém a mesma é oferecida originalmente à outro curso de graduação, ou seja, a disciplina oferecida não tem como objetivo principal atender os cursos de formação de professor, porém está disponível como uma disciplina optativa; dois cursos possuem a disciplina optativa, que aborda temas de Matemática Financeira e a mesma é oferecida e pensada para o curso de licenciatura em matemática; três cursos que possuem a disciplina obrigatória, que aborda temas de Matemática Financeira e a mesma é oferecida para o curso de formação de professores e um que curso possui a disciplina obrigatória de Educação Financeira e é oferecida para o curso de formação de professores.

A análise das grades curriculares levou em consideração aquelas que estavam vigentes no ano de 2017, e em cada grade as disciplinas que possuíam conteúdos de Educação Financeira e/ou Matemática Financeira. 


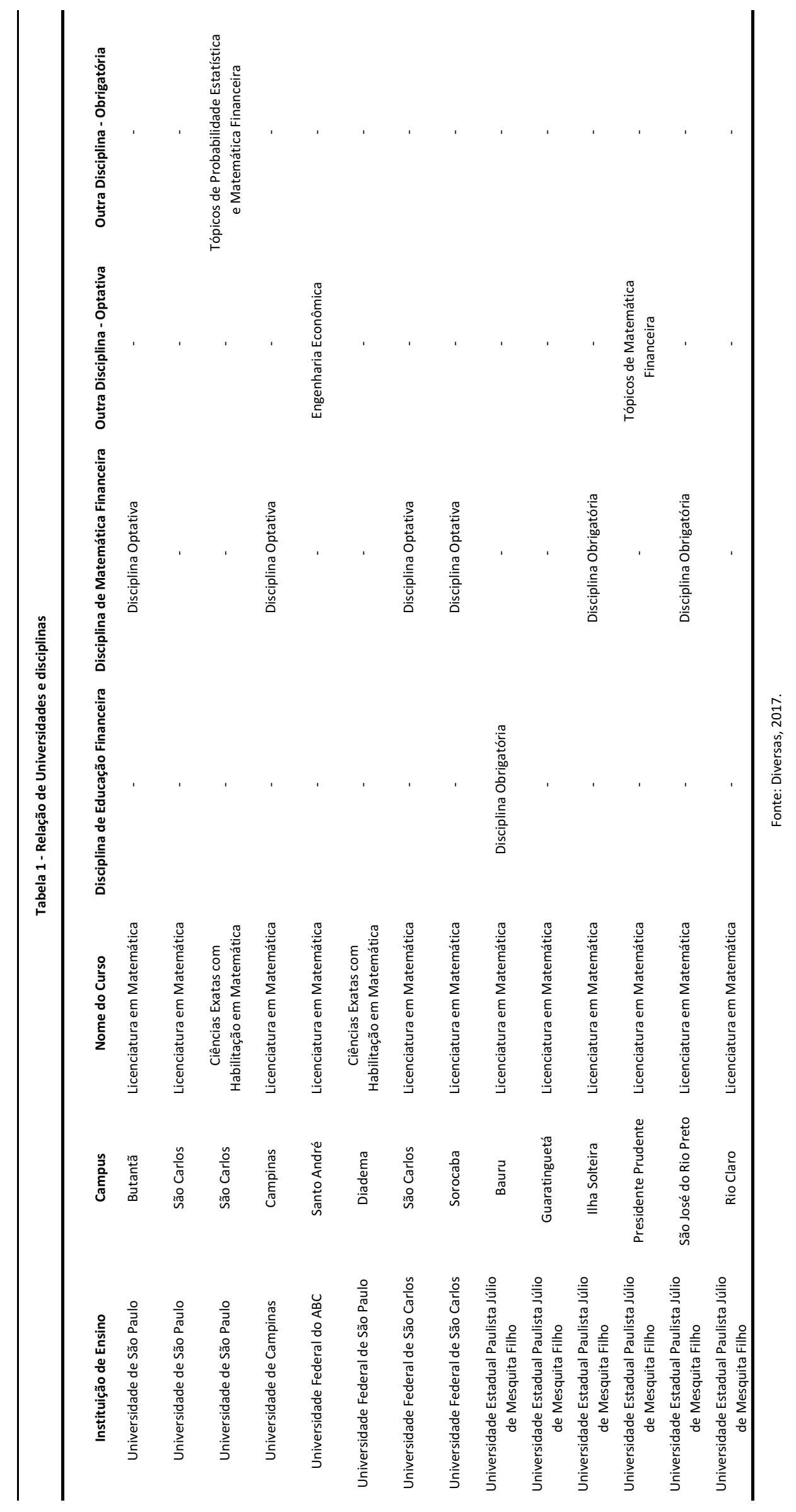


A seguir, apresentamos dados das disciplinas analisadas, lembrando que como a análise das grades aconteceu no final de 2017 e como cursos de graduação estão em constante reformulação, para devidas e necessárias atualizações e ajustes, podem ter havido mudanças que por motivos temporais claros não foram analisadas neste trabalho.

a) Universidade de São Paulo (campus Butantã) - Curso de Licenciatura em Matemática

O estudante de licenciatura em matemática pode cursar como optativa livre a disciplina Matemática Financeira (EAC0217) oferecida pelo pela Faculdade de Economia e Administração originalmente os cursos de bacharelado de Economia, Contabilidade, Administração e Atuária.

Ementa da disciplina

Abordar os conceitos básicos da Matemática Financeira incorporando teoria e aplicações, sobretudo no campo de Ciências Contábeis.

b) Universidade de São Paulo (campus de São Carlos) - Curso de Licenciatura em Matemática

Não encontramos nenhuma disciplina obrigatória e/ou optativa de Matemática Financeira e/ou Educação Financeira ou outra disciplina com nome distinto que aborde tais assuntos.

c) Universidade de São Paulo (campus de São Carlos) - Curso de Ciências Exatas com Habilitação em Matemática

O estudante desta habilitação deve cursar, preferencialmente no quarto ano, a disciplina obrigatória Tópicos de Probabilidade, Estatística e Matemática Financeira (SLC0611) oferecida pelo Instituto de Ciências Matemáticas e de Computação. 


\section{Ementa da disciplina}

Números Racionais e Irracionais: definição de números racionais, representações decimais finitas e infinitas, dízimas periódicas. Análise Combinatória: princípio fundamental da contagem (ou multiplicativo), permutações, combinações, arranjos, permutações circulares, permutações de elementos nem todos distintos. Probabilidade: espaço amostral e probabilidades de Laplace, espaços de probabilidade, probabilidades condicionais, independência. Tratamento da Informação: médias, mediana, moda e desvio padrão; tabela de frequências, representações gráficas de dados discretos e contínuos. Matemática Financeira: introdução, juros e capitalização simples, juros compostos, descontos e taxa de desconto, séries de pagamento, sistemas de amortização.

\section{d) Universidade de Campinas (campus Campinas) - Curso de Licenciatura em Matemática}

O estudante de licenciatura em matemática pode cursar como optativa livre de Matemática Financeira (MS317) oferecida pelo Instituto de Matemática, Estatística e Computação.

\section{Ementa da disciplina}

Noção de taxa de juros. Fluxos de caixa. A calculadora financeira. Operações financeiras. Mercado financeiro. Sistemas de amortização e planilhas financeiras. Comparação entre alternativas de investimento. Extensões.

\section{e) Universidade Federal do ABC (campus de Santo André) - Curso de Licenciatura em Matemática}

Não encontramos nenhuma disciplina com o nome de Educação Financeira e/ou Matemática Financeira nesta Universidade, porém encontramos a disciplina de Engenharia Econômica (BC1711), que é uma disciplina obrigatória do ciclo básico dos cursos de bacharelado em engenharia e uma disciplina optativa livre para os demais cursos de graduação, incluindo o de licenciatura em matemática. 
Ementa da disciplina

Conceitos de Engenharia Econômica; Elementos de Matemática Financeira aplicados em engenharia econômica: juros, taxas de juros, diagrama do fluxo de caixa, juros simples, juros compostos. Valor Presente e Valor Futuro de Fluxos de Caixa: Série Uniforme, Série Não Uniforme, Série Gradiente, Série Perpétua. Métodos de Avaliação de Projetos de Investimentos: conceito de Taxa Mínima de Atratividade, Classificação de Projetos, Valor Residual, Vidas Úteis dos Projetos, Fluxo de Caixa de Projetos. Métodos de Avaliação de Projetos de Investimentos: Pay-back; Pay-back Descontado; Valor Presente Líquido (VPL), Índice de Lucratividade (IL); Taxa Interna de Retorno (TIR); Taxa Interna de Retorno Modificada (MTIR). Depreciação: conceitos - depreciação real e depreciação contábil. Métodos de cálculo de depreciação (linear, soma dos dígitos, taxa constante, quantidade produzida).

f) Universidade Federal de São Paulo (campus de Diadema) - Curso de Ciências Exatas com Habilitação em Matemática

Não encontramos nenhuma disciplina obrigatória ou optativa de Matemática Financeira e/ou Educação Financeira ou ainda alguma outra disciplina que contemple assunto relacionas em sua ementa.

g) Universidade Federal de São Carlos (campus de São Carlos e de Sorocaba) - Curso de Licenciatura em Matemática

O estudante de licenciatura em matemática deve cursar a disciplina Matemática Financeira que é obrigatória para os graduandos do curso de bacharelado em Ciências Econômicas e optativa para os demais cursos de graduação.

Ementa da disciplina

Juros e Regimes de Capitalização Simples e Composta. Equivalência de Capitais e Equivalência de Taxas. Operações de Desconto. Séries de Pagamento Uniformes e não Convencionais. Fluxos de Caixa. Métodos de Avaliação de Fluxos de Caixa. Sistemas de Amortização. Critério de Avaliação de 
investimento: taxa interna de retorno e valor presente líquido. Yield to Maturity de um título de renda fixa.

h) Universidade Estadual Paulista Júlio de Mesquita Filho (campus de Bauru) - Curso de Licenciatura em Matemática

O estudante de licenciatura em matemática deve cursar, preferencialmente no primeiro ano de graduação, a disciplina Educação Financeira (5107A) é obrigatória e oferecida pela Faculdade de Ciências - responsável pelo curso de licenciatura em matemática deste campus.

Ementa da disciplina

Progressão aritmética; Progressão geométrica; Conceitos básicos de Matemática Financeira: os fatores de correção e o valor do dinheiro no tempo; Matemática comercial e financeira: conceitos básicos, juros e descontos; Capitalização e amortização compostas: rendas certas ou anuidades e sistemas de amortização; Exploração de calculadoras (científica e financeira) e de planilha eletrônica no estudo e investigação dos conteúdos de Matemática Financeira; Elaboração de atividades voltadas à prática nos ensinos fundamental II e médio abordando os conteúdos da disciplina e utilizando metodologias diferenciadas.

i) Universidade Estadual Paulista Júlio de Mesquita Filho (campus de Guaratinguetá) - Curso de Licenciatura em Matemática

Não encontramos nenhuma disciplina obrigatória ou optativa de Matemática Financeira e/ou Educação Financeira ou ainda alguma outra disciplina que contemple assunto relacionas em sua ementa.

\section{j) Universidade Estadual Paulista Júlio de Mesquita Filho (campus de Ilha} Solteira) - Curso de Licenciatura em Matemática

O estudante de licenciatura em matemática deve cursar, preferencialmente no segundo ano, a disciplina obrigatória Matemática Financeira (0730) oferecida 
pela Faculdade de Ciências - responsável também pelo curso de licenciatura em matemática do campus de Ilha Solteira.

\section{Ementa da disciplina}

Juros simples e compostos; Descontos; Amortização.

k) Universidade Estadual Paulista Júlio de Mesquita Filho (campus de Presidente Prudente) - Curso de Licenciatura em Matemática

O estudante de licenciatura em matemática pode cursar como optativa eletiva Tópicos de Matemática Financeira e é oferecida pela Faculdade de Ciências e Tecnologia do Campus de Presidente Prudente.

Ementa da disciplina

Juros e capitalização simples. Capitalização composta. Desconto e taxa de desconto. Câmbio. Capitalização e amortização. Empréstimo.

I) Universidade Estadual Paulista Júlio de Mesquita Filho (campus de São José do Rio Preto) - Curso de Licenciatura em Matemática

O estudante de licenciatura em matemática deve cursar, preferencialmente no quarto ano de graduação a disciplina obrigatória Introdução a Matemática Financeira (1489S) oferecida pela Faculdade de Ciências do Campus de São José do Rio Preto.

\section{$\underline{\text { Ementa da disciplina }}$}

Juros simples e compostos. Séries periódicas uniformes. Planos de amortização de empréstimos e financiamento. Inflação: índices de preços; taxas de juros aparente e real. Avaliação de investimentos.

m) Universidade Estadual Paulista Júlio de Mesquita Filho (campus de Rio Claro) - Curso de Licenciatura em Matemática 
Não encontramos nenhuma disciplina obrigatória e/ou optativa de Matemática Financeira e/ou Educação Financeira ou ainda alguma outra disciplina que contemple assunto relacionas em sua ementa.

Observemos então que dentre todos os cursos encontrados na busca realizada na página do e-MEC, apenas o curso de licenciatura em matemática da UNESP campus Bauru possui uma disciplina obrigatória de Educação Financeira em sua grade curricular, além disso, pode-se observar que a ementa contempla aspectos voltados à formação do professor de matemática. Destacamos também, que existem cursos de licenciatura em matemática ou de ciências exatas com habilitação em matemática em que não foram encontradas disciplinas que abordem temas relacionados a Educação Financeira ou Matemática Financeira em suas grades curriculares.

Em outros três cursos de licenciatura, existem disciplinas cujos nomes não são Matemática Financeira ou Educação Financeira, mas que que abordam temas de Educação Financeira e/ou Matemática Financeira em suas ementas. O primeiro é o curso de ciências exatas com habilitação em matemática da USP do campus São Carlos, que possui a disciplina obrigatória Tópicos de Probabilidade, Estatística e Matemática Financeira em sua grade curricular com temas de Matemática Financeira, o segundo é o curso de licenciatura em matemática da UFABC do campus Santo André, que possui uma disciplina optativa de Engenharia Econômica, é oferecida para outros cursos de graduação no mesmo campus, a terceira é o curso de licenciatura em matemática da UNESP do campus Presidente Prudente, que possui uma disciplina optativa na grade curricular com temas de Matemática Financeira abordado na disciplina Tópicos de Matemática Financeira.

Os cursos da UNESP dos campi Ilha Solteira e São José do Rio Preto, ambos possuem a disciplina de Matemática Financeira como obrigatória na grade curricular. Somente o curso de licenciatura em matemática na UNICAMP do campus Campinas possui a disciplina optativa de Matemática Financeira específica para a licenciatura, já que para os demais cursos das outras Universidades, a disciplina de Matemática Financeira é uma disciplina optativa oferecida originalmente para outro curso de graduação.

Cabe ressaltar que as disciplinas optativas que não são oferecidas especificamente para os cursos de formação de professores, sendo assim podendo gerar um viés quanto às discussões e o objetivo, já que os temas podem não ser discutidos em situações que envolvam a preocupação com a sala de aula do ensino fundamental e médio, como por exemplo, a 
estreita relação entre progressões aritmética, geométrica e os sistemas de amortização presentes na Matemática Financeira e a discussão de como estes podem ser utilizados com adolescentes do ensino médio.

Visto isto, com o intuito de obtermos mais detalhes de como o tema de Educação Financeira é abordado em sala de aula para os futuros professores em sua formação inicial, realizamos duas etapas de pesquisa que serão detalhadas. A primeira etapa foi o envio de um questionário online enviado para os alunos que realizaram ou estavam realizando a graduação no curso de licenciatura em matemática na UNESP do campus Bauru e na UNESP do campus Rio Claro. Enviamos o questionário para os alunos de licenciatura em Matemática da UNESP campus Bauru, pois este era o único curso que apresentava uma disciplina de Educação Financeira em sua grade e para os alunos da UNESP campus Rio Claro, pois gostaríamos de verificar a não existência de uma disciplina optativa e/ou obrigatória que aborde temas de Educação Financeira ou de Matemática Financeira. Não enviamos o questionário para os alunos do curso de licenciatura em matemática da Universidade de São Paulo campus São Carlos, pois a grade curricular não possui créditos para disciplinas optativas livres, ao contrário da UNESP campus Rio Claro.

A segunda etapa da pesquisa foi uma entrevista com a docente da UNESP do campus Bauru que lecionou a disciplina de Educação Financeira para os licenciandos em matemática nos últimos dois anos.

\subsection{A primeira etapa da pesquisa}

O questionário é uma das técnicas mais utilizadas como instrumento de coleta de dados, sendo assim, a nossa primeira etapa da pesquisa foi realizada através de um questionário online.

Elaboramos questões com o objetivo de que das respostas, pudéssemos obter mais detalhes sobre a disciplina de Educação Financeira e como a mesma era abordada dentro da sala de aula para preparar os atuais licenciandos e consequentemente alguns futuros professores de matemática. Visto que a própria pesquisa nos conduziu apenas para a UNESP do campus Bauru, entramos em contato via mensagem eletrônica com a coordenadora do curso de licenciatura em matemática deste campus em setembro de 2017 com o objetivo de 
questionar sobre a possibilidade de encaminhar uma pesquisa aos alunos que estavam cursando a disciplina de Educação Financeira naquele mesmo semestre, pois a mesma é oferecida apenas no segundo semestre de cada ano. Após o primeiro contato a coordenadora do curso de licenciatura em matemática, a mesma nos colocou em contato direto com a docente que estava lecionando a disciplina naquele mesmo semestre, e esta nos forneceu a listagem com os endereços eletrônicos dos alunos formados em 2016 e dos alunos que estavam cursando a disciplina no semestre em questão para que pudéssemos enviar o questionário.

Enviamos o mesmo questionário para um grupo de uma rede social que dizia ter apenas alunos do curso de licenciatura em matemática da UNESP do campus Rio Claro, com o objetivo de investigar se de fato não existia alguma disciplina abordando temas de Educação Financeira e/ou Matemática Financeira, pois não encontramos nenhuma disciplina, optativa e/ou obrigatória neste campus que abordasse tais temas.

O questionário apresentava perguntas sobre quais os conteúdos foram ministrados nas disciplinas de Educação Financeira e/ou Matemática Financeira, na opinião do entrevistado, quais foram as contribuições da disciplina para a formação do aluno como um futuro professor de matemática, se temas como ética e sustentabilidade foram discutidos em sala de aula e dentre outras. As perguntas do questionário conduziam à próxima pergunta dependendo da resposta que o entrevistado desse, por exemplo, na questão 6 , que versava sobre qual disciplina o estudante havia cursado em sua graduação.

6. Com relação as disciplinas durante a graduação, responda:

( ) Cursou somente a disciplina Educação Financeira

( ) Cursou somente a disciplina Matemática Financeira

( ) Cursou as disciplinas Educação Financeira e Matemática Financeira

( ) Nenhuma das alternativas anteriores 
Se o aluno respondesse que cursou somente a disciplina de Educação Financeira, era direcionado apenas para as perguntas 15, 16, 17 e 18 específicas sobre Educação Financeira como descrevemos a seguir.

15. Na disciplina de Educação Financeira foram discutidos temas como: ética, sustentabilidade, equilíbrio financeiro, consumo e etc?

( ) $\mathrm{Sim}$

( ) Não

16. Descreva o que você estudou durante o curso de Educação Financeira.

17. Qual foi a contribuição da disciplina de Educação Financeira para a sua formação como professor?

18. Dê um exemplo de como você trabalharia Educação Financeira em salas de aula da Educação Básica.

Caso o aluno respondesse que cursou somente a disciplina de Matemática Financeira, era direcionado para as perguntas 10, 11, 12, 13 e 14 sobre Matemática Financeira, como explicitado a seguir.

10. Descreva o que você estudou durante seu curso de Matemática Financeira.

11. Na sua opinião, qual foi a contribuição da disciplina de Matemática Financeira para a sua formação como professor?

12. Dê um exemplo de como você trabalharia Matemática Financeira em salas de aula da Educação Básica.

13. O que você entende sobre a Educação Financeira? 
14. Como você trabalharia Educação Financeira em salas de aula da Educação Básica?

Se o respondente marcasse que cursou a disciplina de Matemática Financeira e a disciplina de Educação Financeira, logo era direcionado para as perguntas 19, 20, 21 e 22.

19. Na disciplina de Educação Financeira foram discutidos temas como: ética, sustentabilidade, equilíbrio financeiro, consumo e etc?

( ) $\operatorname{Sim}$

( ) Não

20. Descreva o que você estudou durante o curso de Educação Financeira e durante o curso de Matemática Financeira destacando as principais diferenças e similaridades.

21. Qual foi a contribuição da disciplina de Educação Financeira e da disciplina de Matemática Financeira para a sua formação como professor?

22. Você acredita que cursar essas duas disciplinas foi fundamental para a sua formação?

( ) $\operatorname{Sim}$

( ) Não

( ) Talvez

E por fim, caso o aluno respondesse que não cursou a disciplina de Matemática Financeira e nem disciplina de Educação Financeira, era direcionado para perguntas sobre a existência de uma outra disciplina que poderia ter abordado tais temas.

Com o intuito de obter um maior número de respondentes, o questionário foi enviado duas vezes, com a preocupação de que quem já havia respondido não fosse contado em 
duplicidade, o primeiro envio foi realizado em setembro de 2017 e o segundo envio realizado em maio de 2018 e obtivemos um total de 14 respondentes distintos somando-se as duas rodadas de envio. Para maiores detalhes o questionário pode ser consultado na integra no Apêndice A e na página https://forms.gle/4tsCsV4iZoydooHp6.

\subsection{A segunda etapa da pesquisa}

A segunda etapa da pesquisa foi uma entrevista que está transcrita em sua completude no Apêndice B, com a docente da disciplina de Educação Financeira da UNESP do campus Bauru.

A entrevista é uma técnica de coleta de dados utilizada no processo exploratório, pois através desta técnica é possível obter mais informações de um tema específico de um outro ponto de vista, o do entrevistado.

[...] um processo de interação social entre duas pessoas na qual uma delas, o entrevistador, tem por objetivo a obtenção de informações por parte do outro, o entrevistado. (HAGUETTE, 1997)

Uma das etapas mais importantes dessa técnica de coleta de dados é a preparação da entrevista, pois requer cuidados como: planejamento das questões de acordo com o objetivo de pesquisa, a escolha dos entrevistados e disponibilidade de tempo. Uma entrevista pode ser classificada em três principais tipos:

a) Não-estruturada: quando não possui o roteiro previamente estabelecido.

b) Semiestruturada: quando tem um roteiro com perguntas abertas, porém tem flexibilidade na apresentação das perguntas ao entrevistado e ainda o entrevistador pode fazer perguntas complementares. 
c) Estruturada: quando tem um roteiro prévio, as perguntas são fechadas. O roteiro de perguntas é utilizado com o entrevistado na mesma sequência em que foi elaborado.

Neste trabalho optamos pela entrevista do tipo semiestruturada, pois nos permitiu elaborar perguntas prévias com intuito de entender melhor nosso objeto de pesquisa, mas que ao mesmo tempo nos possibilitou intervenções quando fossem pertinentes.

As perguntas foram elaboradas com o objetivo de obter informações sobre os conteúdos ministrados, abordagens feitas e discussões realizadas durante a disciplina de Educação Financeira dos futuros professores de matemática deste campus, ou seja, informações sobre o conteúdo fornecido aos estudantes, como a abordagem dos conteúdos são tratadas para que o futuros professores possam ensinar em sala de aula da educação básica, se possui conteúdos que possam auxiliar o futuro professor em sala de aula, quais foram os conteúdos fornecidos.

A seguir apresentamos o roteiro elaborado e seguido durante a entrevista

1. O que você entende por Educação Financeira? E como foi pensada a introdução dessa disciplina na grade curricular?

2. Quando foi a inclusão da disciplina Educação Financeira nos cursos de licenciatura em matemática neste campus?

3. O que motivou a inclusão da disciplina Educação Financeira nos cursos de licenciatura em matemática?

4. Como foi o processo de inclusão da disciplina no curso?

5. Que experiências anteriores auxiliaram/guiaram a elaboração da ementa, objetivos e conteúdo do curso de Educação Financeira?

6. Existe algum critério para a atribuição da disciplina? Se sim, qual (is)? 
7. Quais temas, envolvendo ou não matemática, são abordados em sala de aula sobre Educação Financeira? (Discussões em sala de aula sobre diversos outros temas...). Poderia dar exemplos?

8. Na sua opinião, a inclusão da disciplina de Educação Financeira nos cursos de formação inicial de professores de matemática, favorece a exploração do tema em sala de aula?

9. Você acredita ser válida a inclusão da disciplina Educação Financeira na formação inicial do professor de matemática em detrimento de outras? Porquê?

10. Temas como endividamento, parcelamento são discutidos em sala de aula?

11. Após o aprendizado em sala de aula de temas relacionados à Educação Financeira, você percebeu alguma mudança de postura dos alunos quanto à tomada de decisão com relação a finanças?

12. Sobre a ENEF, a senhora tem alguma opinião sobre a ENEF? A composição da ENEF, quem compõe, quem prepara o material e tudo mais?

13. Existe algum motivo específico para somente no campus Bauru ter a disciplina de Educação Financeira?

A entrevista foi realizada no ano de 2019 com a professora que lecionou a disciplina Educação Financeira para o curso de licenciatura em matemática desde o ano de 2016 da UNESP campus Bauru. Apesar da disposição de irmos até o campus Bauru realizar a entrevista pessoalmente, a entrevistada sugeriu a utilização de uma ferramenta eletrônica, sendo assim o contato com a entrevistada foi feita por uma ferramenta eletrônica de comunicação devido a agenda e comodidade para ambas (pesquisadora e entrevistada). 


\section{RESULTADOS}

O envio do questionário, tanto para a lista de endereços eletrônicos fornecida pela coordenação do curso quanto por rede social, foi feito em dois momentos. No primeiro, em setembro de 2017, obtivemos nove respostas sendo quatro de alunos procedentes da UNESP campus Bauru e cinco alunos procedentes do campus Rio Claro. No segundo momento, em maio de 2018, obtivemos duas respostas relativas a Bauru e três respostas relativas a Rio Claro. Uma primeira observação é que do total de questionários respondidos, nove alunos alegaram que estão lecionando, sendo destes quatro formados no curso de licenciatura em matemática da UNESP Bauru e cinco do campus Rio Claro.

Para corroborar com a análise das grades curriculares dos cursos, já descritas no capítulo anterior, em que não foram encontradas disciplinas de Educação Financeira, Matemática Financeira ou outra disciplina com a ementa de conteúdos de Educação Financeira no curso de licenciatura em matemática oferecido pela UNESP do campus Rio Claro, obtivemos, através do questionário a informação de que, todos os alunos da UNESP do campus Rio Claro responderam que não tiveram nenhuma das duas disciplinas (Educação Financeira e/ou Matemática Financeira) e que o tema de Educação Financeira não foi abordado em nenhuma outra disciplina do curso de graduação.

Gráfico 1: Disciplina cursada pelos alunos da UNESP de Rio Claro.

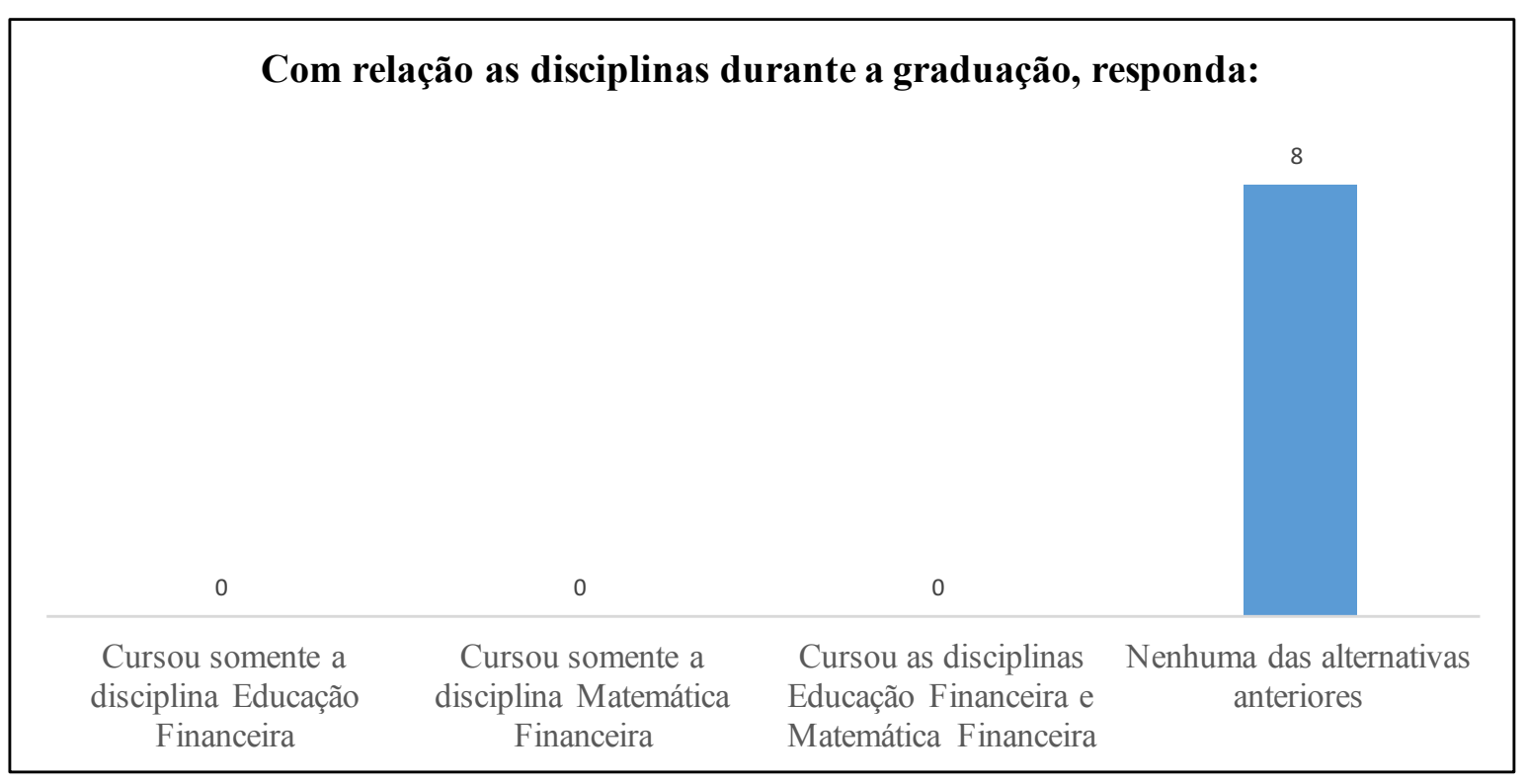

Fonte: Resultado obtido do questionário, 2017/2018. 
Gráfico 2: Abordagem do tema em alguma outra disciplina dos alunos

da UNESP de Rio Claro.

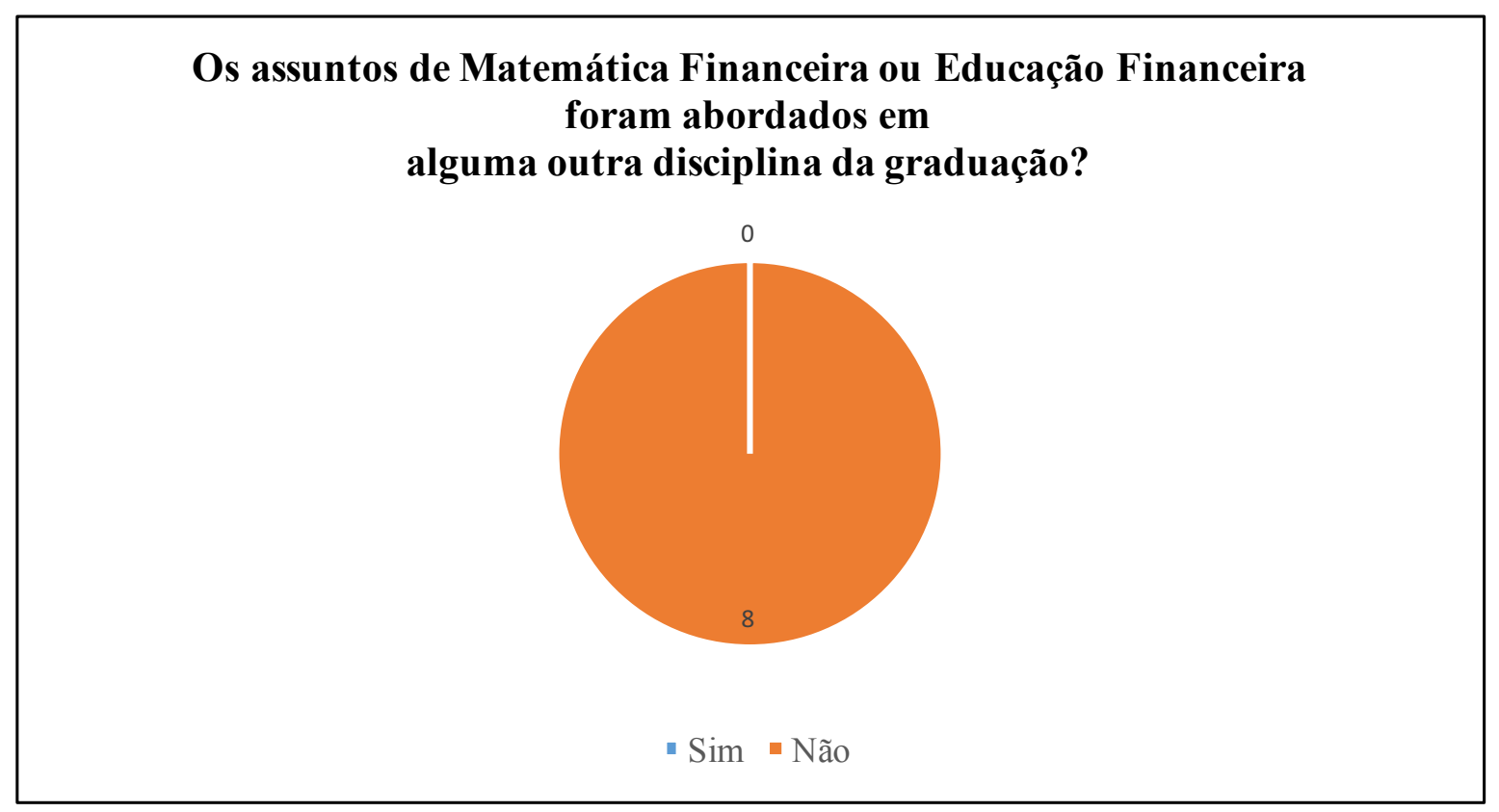

Fonte: Resultado obtido do questionário, 2017/2018.

Como se pode observar no gráfico anterior, os oito alunos da UNESP do campus Rio Claro responderam que os temas de Educação Financeira e/ou Matemática Financeira não são abordados em outra disciplina, enfatizando ainda mais a descrição da pesquisa realizada e apresentada no capítulo anterior de que não existe nenhuma disciplina obrigatória ou optativa que aborde tais temas neste campus para o curso de licenciatura em matemática.

Já dentre os seis alunos da UNESP campus Bauru que responderam ao questionário podemos observar que dois alunos (A e B) cursaram a disciplina de Educação Financeira e quatro alunos (C, D, E e F) cursaram a disciplina de Matemática Financeira. Os quatro alunos C, D, E e F responderam que cursaram a disciplina de Matemática Financeira está no fato de que a grade anterior apresentava Matemática Financeira como obrigatória e esta, posteriormente foi substituída por Educação Financeira, como explicado pela docente na entrevista realizada e que apresentamos no capítulo anterior. 
Tabela 2 - Ementa das disciplinas

Matemática Financeira em 2013

Objetiva-se que os estudantes adquirem conhecimentos de juros e Descontos Simples, Equivalência de capitais Juros Compostos, Anuidade e Empréstimos Sistemas de Amortização e ainda, que eles saibam analisar Alterar de Investimentos por meio de Métodos de Análise, verificando a influência e métodos incorretos, passam ainda construir e usar números índices.

\section{Educação Financeira em 2015}

Progressão aritmética; Progressão geométrica; Conceitos básicos de matemática financeira: os fatores de correção e o valor do dinheiro no tempo; Matemática comercial e financeira: conceitos básicos, juros e descontos; Capitalização e amortização compostas: rendas certas ou anuidades e sistemas de amortização; Uso da calculadora científica e financeira. Uso da Planilha eletrônica na Matemática Financeira.

\section{Educação Financeira em 2017}

Progressão aritmética; Progressão geométrica; Conceitos básicos de matemática financeira: os fatores de correção e o valor do dinheiro no tempo; Matemática comercial e financeira: conceitos básicos, juros e descontos; Capitalização e amortização compostas: rendas certas ou anuidades e sistemas de amortização; Exploração de calculadoras (científica e financeira) e de planilha eletrônica no estudo e investigação dos conteúdos de matemática financeira; Elaboração de atividades voltadas à prática nos ensinos fundamental IIe médio abordando os conteúdos da disciplina e utilizando metodologias diferenciadas.

\section{Educação Financeira em 2018}

Progressão aritmética; Progressão geométrica; Conceitos básicos de matemática financeira: os fatores de correção e o valor do dinheiro no tempo; Matemática comercial e financeira: conceitos básicos, juros e descontos; Capitalização e amortização compostas: rendas certas ou anuidades e sistemas de amortização; Exploração de calculadoras (científica e financeira) e de planilha eletrônica no estudo e investigação dos conteúdos de matemática financeira; Elaboração de atividades voltadas à prática nos ensinos fundamental IIe médio abordando os conteúdos da disciplina e utilizando metodologias diferenciadas.

Fonte: Página da UNESP Bauru, 2018.

As ementas acima foram retiradas da página do curso de licenciatura em matemática do campus de Bauru da UNESP, observe que até 2013 havia a disciplina de Matemática Financeira, não há ementa de Educação Financeira ou Matemática Financeira em 2014 e em 2015 já aparece a ementa da disciplina de Educação Financeira. Podemos afirmar então que a partir de 2015 a disciplina de Educação Financeira foi incluída na grade do curso, não podemos dizer nada a respeito de 2014 , já que não consta essa informação na página do curso, assim como, a docente durante a entrevista não conseguiu precisar se a inclusão da disciplina se deu no ano de 2014 ou de 2015. 
Analisando as ementas da disciplina, podemos observar que a partir do ano de 2015 existem tópicos na ementa que configuram e reforçam a mudança no nome da disciplina de Matemática Financeira para Educação Financeira, além disso, como é natural após os primeiros oferecimentos a disciplina teve sua ementa aprimorada, como notamos no ano de 2017 com relação ao ano de 2015.

De acordo com o relato da entrevistada, antes da mudança da grade, os licenciandos em matemática precisavam cursar a disciplina de Matemática Financeira que era lecionada pelos professores do departamento da Faculdade de Engenharia, ou seja, não era uma disciplina específica para a formação de professores. Somente após a mudança da grade a disciplina deu lugar para um perfil voltado para a formação de professores.

Como que foi pensada a inclusão dessa disciplina no curso de Licenciatura em Matemática?" (Pesquisadora)

"Eu fiz a graduação aqui e era Matemática Financeira, e só que era ministrado por professores da engenharia, por engenheiros. Aí o quê que acontecia? Os alunos reclamavam muito porque era uma matemática pura financeira, assim. Não tinha nenhum contexto com a licenciatura né. Aí a gente lutou muito aqui no departamento pra trazer pra, pro departamento de Matemática! Conseguindo trazer, um dos motivos porque mudar de departamento né? Por que era para dar pro um curso de licenciatura então tinha que ser focado para a licenciatura, então uma das coisas foi mudar ....né, ao invés de dar a Matemática Financeira, dar a Matemática Financeira voltada para a área de educação, é associando com as notícias do dia a dia e de uma maneira com uma abordagem que o aluno pode passar pros alunos do ensino fundamental do ensino básico, qualquer que seja né. Então um dos motivos foi esse!" (Entrevistada)

"Hum, entendi! E como foi esse processo da inclusão dessa disciplina no curso de Licenciatura em Matemática? Foi simples? Foi dificil colocar na grade?" (Pesquisadora) 
"Não, é, só trocou né a Matemática Financeira pela Educação Financeira, então de colocar na grade...,não teve dificuldade nenhuma né."'(Entrevistada)

O fato da disciplina Educação Financeira ter sido incluída na grade pelo departamento responsável pelo curso de licenciatura em matemática e também ser lecionada por docentes deste departamento, tornou possível a inclusão de contextualizações e preocupações com a educação básica, como se pode notar na ementa. A preocupação com conteúdos matemáticos como juros simples, compostos, capitalização, amortização, e outros que aparecem tanto na ementa de Matemática Financeira como na ementa de Educação Financeira; corroborado pelas respostas dos estudantes A, D, E e F apresentadas a seguir; podem estar agora acompanhados de discussões pertinentes a formação de professor.

"Regimes de capitalização, lucros sobre preço de custo, lucro sobre preço de venda e sistemas de amortização." (Aluno A)

"Sistema de juros simples e compostos, análise de investimento de capitais." (Aluno D)

"Sistema Price, SAC, amortização entre outros cálculos." (Aluno E)

“Juros simples e compostos, variação de taxa e similares. Nada muito além do comum que é visto nas escolas." (Aluno F)

Observe que as respostas dos estudantes D, E e F, que cursaram Matemática Financeira anteriormente a alteração da grade, e a ementa do curso de Matemática Financeira nos mostram que conteúdos essenciais como sistemas de capitalização, sistemas de amortização e outros já eram ensinados, mas a atenção a formação do professor de matemática não é mencionada em ambos os casos. A alteração abre possibilidade para que essa preocupação, com o futuro professor, exista e seja abordada, como podemos observar no relato da atual docente da disciplina de Educação Financeira. 
A seguir apresentamos um trecho da entrevista com a docente em que podemos observar que além de conteúdos e fórmulas matemáticas, existe a preocupação com a Educação Financeira e com as possíveis contextualizações dos assuntos abordados. Neste mesmo trecho a entrevistada apresenta um exemplo de contextualização que se lembrou no momento da entrevista.

"Você consegue dar um exemplo pra mim professora de um tema que você trata dentro de sala de aula?" (Pesquisadora)

“Ah, costuma se pegar coisas do jornal... ”(Entrevistada)

“Aham.” (Pesquisadora)

"Recortes de jornal e aí tem monte de índice, um monte de, de... Até o ano passado foi bem legal, peguei um recorte de jornal e tinha um monte de indice e um monte de notícia assim, hum é, errada! Né, e na hora que a gente foi passando o tempo e a gente foi fazendo as percentagens, abordando né, os conceitos, tudo.

Ahmmm... Os alunos foram vendo que tava a noticia tava tendenciosa para o governo né. Pra, pra beneficiar o governo em questão né, então. Mas assim eu não saio do assunto da área de economia, de finanças, dessas coisas não!” (Entrevistada)

A Educação Financeira engloba e dá margem à diversas possíveis discussões dos mais variados temas, como exemplo, em nossa pesquisa questionamos, tanto alunos como a docente, a respeito de temas como ética e sustentabilidade, mas infelizmente não conseguimos respostas afirmativas a respeito da existência de discussões sobre esses temas. Tanto os estudantes A e B como a docente quando questionados sobre a existência de discussões sobre ética e sustentabilidade responderam que esses assuntos não foram abordados no curso. 
"Entendi, mas ôh professora temas como por exemplo de ética e sustentabilidade. Eles são discutidos dentro de sala de aula? Porque assim, a gente gostaria de entender quais são os temas extra matemática que são discutidos dentro da Educação Financeira?"'(Pesquisadora)

“Hum, não! A parte de ética não! A gente discute assim, notícias do dia a dia mesmo, tem a ver com a economia, com a parte financeira do país, fora isso, não!” (Entrevistada)

Por outro lado, a ENEF, como descrito ao longo deste trabalho, descreve que a Educação Financeira tem por objetivo possibilitar aos indivíduos uma melhor compreensão de conceitos e produtos financeiros, o exemplo informado pela docente em sua entrevista nos mostra que eles estão tendo contato com esses produtos não só em seu cotidiano, mas também em suas aulas de Educação Financeira, o que julgamos importante tanto para a formação do indivíduo como também à do futuro professor de matemática.

"Entendi! Você acha que a disciplina possibilita para as pessoas que estão aprendendo mesmo os próprios licenciando a tomada de decisão um pouco mais consciente?" (Pesquisadora)

“Ahhh, sim!” (Entrevistada)

"Você acredita que sim?” (Pesquisadora)

"Que a gente vê a surpresa deles assim quando você fala sobre a inflação, como que é calculado a taxa, ai eles falam: Nossa! Por isso que é aquele absurdo a taxa que a gente nunca sabe de onde saí! Né. Ah e quando vai para as tabelas de financiamento, que a gente pega exemplos da Caixa, faz a simulação no computador e traz pra sala de aula pra mostrar, então eles..., eu acho que deixa os alunos mais conscientes na hora de fazer alguma, tomar alguma decisão." (Entrevistada) 
Para os autores CAMPOS, TEIXEIRA, COUTINHO (2015), o tema de Educação Financeira pode ser abordado no ambiente escolar de diversas maneira, como por exemplo, para ter um consumo consciente e evitar o consumo desenfreado. Um fato interessante que queremos destacar é a contribuição em sala de aula relatada pela entrevistada de que a disciplina possibilita para os próprios alunos uma tomada de decisão mais consciente com relação as decisões financeiras, como por exemplo, o cálculo de taxas de financiamento, porque temas como esses são abordados em sala de aula.

"Hum entendi. São discutidos temas como por exemplo endividamento, cartão de crédito, parcelamento?" (Pesquisadora)

"Isso! E assim, quando eles compram, compram uma moto e financia e aí traz carnê, ah professora, olha o que aconteceu! ... Ai a gente usa de exemplo na sala entendeu? Então são coisas assim, relacionadas ao dia a dia deles mesmo!" (Entrevistada)

A formação acadêmica do professor possibilita ao mesmo abordar temas em sala de aula com mais segurança e também a relacionar a teoria aprendida com situações cotidianas. De acordo com os autores CAMPOS, TEIXEIRA e COUTINHO (2015) é necessário melhorar a formação dos professores que lecionam a Matemática Financeira, para que os mesmos possam relacioná-la melhor com a Educação Financeira.

Atualmente, ano de 2019, a disciplina Educação Financeira é ministrada por docentes do próprio instituto responsável pelo curso de licenciatura, ao contrário do passado em que a disciplina era denominada de Matemática Financeira e lecionada por docentes da Faculdade de Engenharia, mais especificamente, até hoje somente duas professoras do Instituto de Matemática lecionaram a disciplina, já que a disciplina de Educação Financeira é considerada específica por relacionar discussões das áreas de matemática e educação. E isso pode ser observado na resposta da entrevistada em relação a elaboração da ementa, justificativa, objetivos e bibliografia da disciplina. 
"E tem algum critério professora pro professor lecionar essa disciplina pros alunos de licenciatura ou não?" (Pesquisadora)

“A gente, normalmente tem que ser da área né!" (Entrevistada)

“Tá.” (Pesquisadora)

“Então, aqui o departamento exige, tanto que só eu e mais uma outra professora que pegamos pra dar! Porque ninguém se arrisca assim a lecionar a disciplina. Porque ela é muito específica! Porque se não acaba sendo uma Matemática Financeira pura né!" (Entrevistada)

"Entendi! Para a elaboração da ementa do curso, vocês se basearam em alguma coisa, material, como que foi feito?" (Pesquisadora)

"Sim. Aí, eu não me recordo agora de cabeça, mas foi o material que é Matemática Financeira, Educação Financeira para educadores. Humm ..., puxa, não lembro o nome do autor , mas é uma bibliografia bem específica assim pra, educadores, éhh ..., educa... matemá..” (Entrevistada)

"É especifico de Educação Financeira?" (Pesquisadora)

“Issoooo, pra educadores mesmo!” (Entrevistada)

“Tá. Entendi!" (Pesquisadora)

Para todos os alunos que tiveram a disciplina de Matemática Financeira, todos responderam que não tiveram contribuições significativas para abordar tal tema em sala de aula por diversos motivos como por não ter tido um bom professor e até mesmo pelo conteúdo ensinado em sala de aula estar muito distante do que se leciona na escola. Sendo assim, pode ser que a abordagem do professor em sala de aula tenha sido somente mediante a exposição de fórmulas, pois na ementa do curso, não havia a contextualização do tema com o ensino básico. Já para os alunos que tiveram a disciplina de Educação Financeira, 
responderam que a disciplina não contribuiu de forma significativa porque não se lembravam muito do que foi ensinado em sala de aula além das fórmulas.

Durante a entrevista, a professora destacou que os temas abordados em sala de aula possibilitam aos futuros professores a tratarem o tema nos ensinos fundamental e médio, como por exemplo, a abordagem da progressão geométrica e relacionar com a amortização, ou seja, em sala de aula é demonstrado a teoria de modo que, os futuros professores compreendam em como obter as fórmulas matemáticas.

Contextualizar temas técnicos com situações do dia a dia é algo necessário, pois na própria LDB consta que a educação escolar deve ser vinculada ao cotidiano. Como citado no capítulo anterior, a contextualização é importante em sala de aula, pois de acordo com os autores CAMPOS, TEIXEIRA e COUTINHO (2015), ensinar somente Matemática Financeira sem contextualização de situações reais não basta para promover a Educação Financeira.

Com as análises das respostas do questionário e dos relatos da entrevistada, tivemos as opiniões na perspectiva dos alunos que realizaram as devidas disciplinas, assim como também tivemos a perspectiva da professora que leciona a disciplina Educação Financeira atualmente.

$\mathrm{Na}$ perspectiva dos alunos, diante das respostas, pudemos verificar que os temas tratados em sala de aula são sistemas de amortização, cálculo de juros e capitalização, e temas como ética, sustentabilidade e conscientização não são abordados em sala de aula. Apesar das respostas dos alunos que tiveram a disciplina de Educação Financeira ser de que aprenderam somente fórmulas matemáticas, não ficou evidente que não foi tratado a abordagem das fórmulas com alguma contextualização, pois na ementa da disciplina consta a elaboração de atividades voltada para a educação básica. Já para os alunos que tiveram a disciplina de Matemática Financeira, estes responderam que tiveram somente fórmulas matemática, porém na ementa da disciplina não consta a contextualização das fórmulas com atividades educacionais.

Na perspectiva da entrevistada, compreendemos que a atual disciplina de Educação Financeira é uma disciplina que relaciona as ferramentas matemáticas com situações do cotidiano, e temas como sustentabilidade, ética não são discutidos em sala de aula. Mas 
observamos que os produtos financeiros são tratados em sala de aula, pois a mesma destacou um exemplo da tal abordagem em sala de aula durante a entrevista, melhorando a compreensão de um financiamento, assim como a ENEF estabelece que "A Educação Financeira possibilita que os indivíduos e as sociedades melhorem sua compreensão em relação aos conceitos e produtos financeiros", (BRASIL, 2010).

De acordo com CAPRONI, no Brasil, poucas pessoas possuem o hábito de fazer planejamento financeiro, e como não possuem o hábito de praticar, logo também não se ensina, mas de acordo com o relato da entrevistada são discutidos em sala de aula temas como endividamento, cartão de crédito e parcelamento e que a disciplina possibilita para os próprios alunos uma tomada de decisão mais consciente.

As informações históricas da disciplina foram importantes, pois anteriormente existia a disciplina de Matemática Financeira na grade curricular e a mesma era oferecida por professores da Escola de Engenharia da UNESP do campus Bauru. Depois de várias discussões internas, a disciplina de Matemática Financeira passou a ser oferecida por professores do próprio Instituto de Matemática com o objetivo de relacionar o tema da Matemática Financeira com a educação, e não somente a exposição das fórmulas sem nenhuma contextualização. Essa transferência da disciplina para o próprio Instituto de Matemática possibilitou aos professores contextualizar a Matemática Financeira com a educação básica, de modo, a não ser apenas uma exposição de fórmulas matemáticas sem contextualização, sendo assim, se tornando atualmente a disciplina de Educação Financeira.

Compreendemos também, que a disciplina possibilita ao estudante uma autoconscientização com relação as finanças, conhecimento de fórmulas matemáticas e até algumas aplicabilidades, como por exemplo, o financiamento de uma moto que foi citado na entrevista, pois solucionar os problemas do dia a dia que os alunos estão inseridos com a teoria aprendida é o papel do professor de acordo com o autor KISTEMANN, ALMEIDA E NETO (2017).

Vimos no capítulo anterior, que o tema de Educação Financeira está sendo abordado na LDB e na BNCC. Nos PCNs de Matemática, consta a possiblidade para inserir o tema. Logo, é necessário que o mesmo seja discutido na sala de aula, como indica a OCDE que o tema de Educação Financeira deveria ser ensinado nas escolas. 
Dadas as pesquisas realizadas, dentre todos os cursos pesquisados em várias Universidades, obtivemos que a UNESP do campus Bauru possui a disciplina de Educação Financeira no curso de licenciatura em matemática. A existência de um único campus que aborda o tema de Educação Financeira nos cursos de formação de professores de matemática possibilita a promoção da Educação Financeira para os futuros professores, e que por mais que a disciplina tenha suas deficiências, temos que a mesma é uma disciplina nova e recente e que tem sido aprimorada ao longo do tempo. 


\section{CONCLUSÃO}

O tema de Educação Financeira foi recentemente inserido na LDB, na BNCC e nos PCN's de Matemática e talvez seja este motivo por não haver o tratamento do tema na formação de professores de matemática em todas as Universidades Públicas do Estado de São Paulo.

Inicialmente consultamos na página do Ministério da Educação os cursos presenciais de licenciatura em matemática das Universidades Públicas do Estado de São Paulo. Através dessa pesquisa, analisamos as ementas das disciplinas dos cursos e obtivemos que apenas um único curso de licenciatura em matemática possui uma disciplina de Educação Financeira.

Encontramos um único curso de licenciatura em matemática que possui a disciplina de Educação Financeira, logo fomos investigar como a mesma é abordada em sala de aula para os futuros professores de matemática. Com o objetivo de investigar quais temas eram abordados na disciplina e como a disciplina possibilitaria aos futuros professores de matemática abordar tal tema em sala de aula, realizamos a pesquisa em duas etapas, a primeira etapa elaboramos um questionário online com questões sobre o tema e enviamos para os alunos que concluíram o curso de licenciatura ou estavam cursando, e a segunda etapa realizamos uma entrevista à distância com a docente da disciplina para obtermos mais detalhes sobre a abordagem do tema em sala de aula.

O questionário foi uma maneira de alcançarmos informações na perspectiva dos alunos e a entrevista na perspectiva da docente. A entrevista foi importante, pois através dela obtivemos detalhes de como surgiu a disciplina e como a mesma é lecionada, assim como tais temas são tratados em sala de aula.

Obtivemos quatorze respostas com o questionário, sendo seis respostas dos alunos da UNESP do campus Bauru e oito respostas de alunos da UNESP do campus Rio Claro. Dentre os seis alunos da UNESP do campus Bauru, dois alunos cursaram a disciplina de Educação Financeira e quatro alunos cursaram a disciplina de Matemática Financeira. Os 
quatro alunos que cursaram a disciplina de Matemática Financeira, foi devido, a disciplina de Educação Financeira ter sido inserida na grade curricular recentemente.

De acordo com as respostas obtidas dos alunos e da entrevistada, os temas de sustentabilidade e ética não são discutidos em sala de aula.

Para os alunos, ambas as disciplinas abordaram somente a exposição de fórmulas, porém para os alunos que cursaram a disciplina de Educação Financeira, estes não deixaram claro a ausência da contextualização das fórmulas com atividades voltadas para a educação básica, por isso, não podemos afirmar que a disciplina não aborda a contextualização com a educação, pois na ementa da disciplina consta essa contextualização, assim como em diversos trechos da entrevista com a docente da disciplina cita tal contextualização.

Para a docente, a disciplina é lecionada contextualizando a Matemática Financeira com situações do dia a dia dos alunos, não somente uma Matemática Financeira mediante a exposição de fórmulas. De acordo com os autores CAMPOS, TEIXEIRA, COUTINHO (2015), a Educação Financeira é um instrumento de tomada de decisões financeira. Uma situação que merece destaque é o exemplo citado pela entrevistada abaixo:

"Hum entendi. São discutidos temas como por exemplo endividamento, cartão de crédito, parcelamento?" (Pesquisadora)

"Isso! E assim, quando eles compram, compram uma moto e financia e aí traz carnê, ah professora, olha o que aconteceu! ... Ai a gente usa de exemplo na sala entendeu? Então são coisas assim, relacionadas ao dia a dia deles mesmo" (Entrevistada)

Nessa situação citada pela entrevistada podemos ver que ela está educando financeiramente os alunos para que tenham uma tomada de decisão consciente, ou que pelo menos, os alunos tenham uma consciência crítica com relação às finanças, pois de acordo o autor D'AQUINO (2008) é necessário educar o consumidor para que o mesmo possa se tornar equilibrado financeiramente.

Por mais que temas como sustentabilidade e ética não são discutidos dentro da sala de aula, verificamos que os temas de Matemática Financeira são contextualizados com 
situações do dia a dia, e de acordo com uma das definições de Educação Financeira que citamos neste trabalho, temos que a Educação Financeira é definida como a capacidade de fazer julgamentos inteligentes com relação as finanças.

Dado que essa disciplina de Educação Financeira é recente na grade curricular no curso de licenciatura em matemática, vimos que a mesma tem sofrido alterações com relação aos conteúdos da ementa e que atualmente a ementa busca abordar os temas de Matemática Financeira com a educação básica. Os autores CAMPOS, TEIXEIRA, COUTINHO (2005) citam que a Matemática Financeira deve ser contextualizada com situações realísticas para os alunos, sendo assim, observamos que em vários trechos da entrevista, a professora deixou explícito que a disciplina aborda situações cotidianas junto com ferramentas matemáticas para análises, e não somente a exposição de fórmulas sem contextualização nenhuma. Contudo, mesmo diante das respostas dos alunos de que somente fórmulas foram abordadas durante a disciplina, analisamos a ementa e verificamos que a disciplina possibilita a abordagem do tema com atividades voltadas para a educação.

Como já esperávamos, toda disciplina recém inserida, sofre alterações na ementa ao longo do tempo. Compreendemos que as modificações que a ementa da tal disciplina tem sofrido, foi com o objetivo de aprimorar e conquistar uma ementa ideal para uma disciplina de Educação Financeira voltada para a formação de professor, e como todo processo de mudança, existem as suas deficiências. A existência da tal disciplina e a preocupação da docente em como abordar tais temas em sala de aula já é um grande avanço educacional e acreditamos que a disciplina está em evolução e modificação, dado que o próprio tema de Educação Financeira é um tema recente no país e nos normativos da educação brasileira. Visto que o único curso que possui a disciplina de educação financeira para o curso de licenciatura em matemática, acreditamos que o curso ainda sofra alterações com relação a ementa e a abordagem em sala de aula.

Contudo, a existência de um curso de licenciatura em matemática abordando a educação financeira, pode ser um marco inicial para que os demais cursos das demais Universidades planejem futuramente, a abordagem deste tema na grade curricular dos futuros professores de matemática. 


\section{APÊNDICES}




\section{APÊNDICE A - Questionário aplicado aos alunos}

Pesquisa sobre Educação e/ou Matemática Financeira nas Licenciaturas em Matemática das Universidades Públicas do Estado de São Paulo

Concordo em participar, como voluntário (a), da pesquisa sobre Educação e/ou Matemática Financeira nas Licenciaturas em Matemática das Universidades Públicas do Estado de São Paulo que tem como pesquisadora responsável Jéssica Rocha Batista, estudante do Instituto de Matemática e Estatística da Universidade de São Paulo, orientada pelo Prof. Dr. David Pires Dias, os quais podem ser contatados pelo e-mail jessicar@ime.usp.br ou telefone (xx) Xxxxx-Xxxx. O presente trabalho tem por objetivos: Analisar o conteúdo ministrado nas disciplinas de Educação Financeira e/ou Matemática Financeira. Minha participação consistirá em responder este questionário. Compreendo que esse estudo possui finalidade de pesquisa, e que os dados obtidos serão divulgados seguindo as diretrizes éticas da pesquisa, assegurando, assim, minha privacidade. Sei que posso retirar meu consentimento quando eu quiser, e que não receberei nenhum pagamento por essa participação.

1. Nome completo (não é obrigatório se identificar)

2. Você está de acordo com os termos acima? *

( ) ACEITO os termos estabelecidos

Ir para a pergunta 3 .

( ) Não aceito os termos estabelecidos

Ir para "Obrigada".

3. Você fez ou faz o curso de Licenciatura em Matemática? *

( ) Sim, estou cursando a licenciatura.

( ) Sim, já sou licenciado em Matemática.

( ) Não.

( ) Outro: 
4. Em qual Universidade Pública do Estado de São Paulo você se graduou ou está se graduando?*

( ) UFABC

( ) UNICAMP

( ) USP - SÃO CARLOS

( ) USP - BUTANTÃ

( ) UFSCAR - SÃO CARLOS

( ) UFSCAR - SOROCABA

( ) UNESP - BAURU

( ) UNESP - ILHA SOLTEIRA

( ) UNESP - SÃO JOSÉ DO RIO PRETO UNESP

( ) UNESP - RIO CLARO

5. Você lecionou ou está lecionando? *
( ) $\operatorname{Sim}$
( ) Não

6. Com relação as disciplinas durante a graduação, responda: *

( ) Cursou somente a disciplina Educação Financeira Ir para a pergunta 15 .

( ) Cursou somente a disciplina Matemática Financeira Ir para a pergunta 10 .

( ) Cursou as disciplinas Educação Financeira e Matemática Financeira Ir para a pergunta 19 .

( ) Nenhuma das alternativas anteriores Ir para a pergunta 7.

7. Os assuntos de Matemática Financeira ou Educação Financeira foram abordados em alguma outra disciplina da graduação? * 
() $\operatorname{Sim}$

Ir para a pergunta 8 .

( ) Não

Ir para a pergunta 13 .

8. Qual é ou era o nome da disciplina? *

9. Faça uma breve descrição dos conteúdos ministrados nesta disciplina. * Ir para a pergunta 13 .

Obrigada

Pare de preencher este formulário.

\section{Matemática Financeira}

10. Descreva o que você estudou durante seu curso de Matemática Financeira. *

11. Na sua opinião, qual foi a contribuição da disciplina de Matemática Financeira para a sua formação como professor? *

12. Dê um exemplo de como você trabalharia Matemática Financeira em salas de aula da Educação Básica. *

Pare de preencher este formulário.

13. O que você entende sobre a Educação Financeira? * 
14. Como você trabalharia Educação Financeira em salas de aula da Educação Básica? * Pare de preencher este formulário.

\section{Educação Financeira}

15. Na disciplina de Educação Financeira foram discutidos temas como: ética, sustentabilidade, equilíbrio financeiro, consumo e etc? *
( ) $\mathrm{Sim}$
( ) Não

16. Descreva o que você estudou durante o curso de Educação Financeira. *

17. Qual foi a contribuição da disciplina de Educação Financeira para a sua formação como professor? *

18. Dê um exemplo de como você trabalharia Educação Financeira em salas de aula da Educação Básica. *

Pare de preencher este formulário.

\section{Educação Financeira e Matemática Financeira}

19. Na disciplina de Educação Financeira foram discutidos temas como: ética, sustentabilidade, equilíbrio financeiro, consumo e etc? *

( ) $\mathrm{Sim}$ 
( ) Não

20. Descreva o que você estudou durante o curso de Educação Financeira e durante o curso de Matemática Financeira destacando as principais diferenças e similaridades. *

21. Qual foi a contribuição da disciplina de Educação Financeira e da disciplina de Matemática Financeira para a sua formação como professor? *

22. Você acredita que cursar essas duas disciplinas foi fundamental para a sua formação?
( ) $\operatorname{Sim}$
( ) Não
( ) Talvez 


\section{APÊNDICE B - Transcrição da entrevista com a docente}

Entrevistado (a): P. G. C. B.

Tempo de gravação: $15 \mathrm{~min}$

Data: 15 de Abril de 2019

Local: Ferramenta eletrônica

Pesquisadora: Bom, a minha primeira pergunta professora seria o quê que a senhora entende como Educação Financeira?

Entrevistada: Tá! É..., bom, o comum é a Matemática Financeira né?

Pesquisadora: Uhum.

Entrevistada: Aí eu vejo que a nossa disciplina, por ter esse nome de Educação Financeira se diferencia é..., por lidar com a Matemática Financeira é... numa visão de hum, mostrar a Matemática Financeira como os alunos vão ensinar isso na educação básica.

Pesquisadora: Tá.

Entrevistada: Então, então assim educar os alunos que estão recebendo essa disciplina, que estão aprendendo essa disciplina, que muito da disciplina eles já sabem né, parte de juros, percentagem. Então os alunos da graduação já sabem isso e aí a hora que eles estão nessa disciplina na graduação é a visão é como misturar essa parte da financeira na educação básica.

Pesquisadora: Tá.

Entrevistada: Então pra, pra passar essa parte da financeira de uma maneira mais fácil pros alunos da educação, do fundamental né! Como que eles podem passar isso de uma maneira mais fácil pros alunos.

Então, eu vejo dessa forma e, e conscientizando o mesmo da parte financeira da realidade né. É associando as notícias do dia a dia essas coisas assim, é assim que eu vejo! Não só passando a teoria nua e crua da Matemática Financeira.

Pesquisadora: Mas ôh professora, como que foi pensada a inclusão dessa disciplina no curso de Licenciatura em Matemática?

Entrevistada: Na verdade já tinha a Matemática Financeira sempre teve esse né. 
Pesquisadora: Aham.

Entrevistada: Eu fiz a graduação aqui e era Matemática Financeira, e só que era ministrado por professores da engenharia, por engenheiros. Aí o quê que acontecia? Os alunos reclamavam muito porque era uma matemática pura financeira, assim. Não tinha nenhum contexto com a licenciatura né. Aí a gente lutou muito aqui no departamento pra trazer pra, pro departamento de Matemática! Conseguindo trazer, um dos motivos porque mudar de departamento né? Por que era para dar pro um curso de licenciatura então tinha que ser focado para a licenciatura, então uma das coisas foi mudar ....né, ao invés de dar a Matemática Financeira, dar a Matemática Financeira voltada para a área de educação, é associando com as notícias do dia a dia e de uma maneira com uma abordagem que o aluno pode passar pros alunos do ensino fundamental do ensino básico, qualquer que seja né. Então um dos motivos foi esse!

$\mathrm{E}$ a outra foi a exigência do MEC mesmo né, quando mudou toda..., teve que mudar o currículo aqui, a gente teve que incluir né!

Mas aí a gente já tava pensando nisso porque a gente já tinha trazido da engenharia pra cá.

Pesquisadora: Entendi. Você se recorda professora quando que foi a inclusão, o ano em específico da disciplina Educação Financeira?

Entrevistada: Da disciplina? Olha eu não tenho 100\% de certeza, mas eu acho que foi em 2014. 13 ou 14 se não me engano!

Pesquisadora: Hum, entendi! E como foi esse processo da inclusão dessa disciplina no curso de Licenciatura em Matemática? Foi simples? Foi difícil colocar na grade?

Entrevistada: Não, é, só trocou né a Matemática Financeira pela Educação Financeira, então de colocar na grade...,não teve dificuldade nenhuma né. Agora você quer dizer em relação a lecionar?

Pesquisadora: Isso!

Entrevistada: A disciplina? A passar a disciplina? É, a primeira professora que deu a disciplina não não fui eu. Foi a professora Suely. É, pelo que, aí quando eu comecei, ah acho ela deu dois anos e depois eu que peguei. Ela me passou um material que ela usou né, o que 
ela trabalhava, tudo. E no começo foi assim, foi uma transição meio devagar, foi bem devagar assim né, se misturavam muito a Matemática Financeira com a Educação Financeira, tinha pouco de educação né, era mais, mais a matemática mesmo quê a educação. Aí a gente foi aprimorando, foi aprimorando e hoje a gente consegue é focar mais na parte de educação né.

Pesquisadora: Entendi! Para a elaboração da ementa do curso, vocês se basearam em alguma coisa, material, como que foi feito?

Entrevistada: Sim. Aí, eu não me recordo agora de cabeça, mas foi o material que é Matemática Financeira, Educação Financeira para educadores. Humm ..., puxa, não lembro o nome do autor, mas é uma bibliografia bem específica assim pra, educadores, éhh ..., educa... matemá..

Pesquisadora: É específico de Educação Financeira?

Entrevistada: Issoooo, pra educadores mesmo!

Pesquisadora: Tá. Entendi!

Pesquisadora: E tem algum critério professora pro professor lecionar essa disciplina pros alunos de licenciatura ou não?

Entrevistada: A gente, normalmente tem que ser da área né! Pesquisadora: Tá.

Entrevistada: Então, aqui o departamento exige, tanto que só eu e mais uma outra professora que pegamos pra dar! Porque ninguém se arrisca assim a lecionar a disciplina. Porque ela é muito específica! Porque se não acaba sendo uma Matemática Financeira pura né! Pesquisadora: Entendi.

Entrevistada: E como eu mexo com a parte de educação também né. Então me ofereceram e acharam que dava certo e aí eu fiz uma proposta e tô aí! risos...

Pesquisadora: Entendi, mas ôh professora temas como por exemplo de ética e sustentabilidade. Eles são discutidos dentro de sala de aula? Porque assim, a gente gostaria de entender quais são os temas extra matemática que são discutidos dentro da Educação Financeira? 
Entrevistada: Hum, não! A parte de ética não! A gente discute assim, notícias do dia a dia mesmo,

tem a ver com a economia, com a parte financeira do país, fora isso, não!

Pesquisadora: Você consegue dar um exemplo pra mim professora de um tema que você trata dentro de sala de aula?

Entrevistada: Ah, costuma se pegar coisas do jornal...

Pesquisadora: Aham.

Entrevistada: Recortes de jornal e aí tem monte de índice, um monte de, de... Até o ano passado foi bem legal, peguei um recorte de jornal e tinha um monte de índice e um monte de notícia assim, hum ,é, errada! Né, e na hora que a gente foi passando o tempo e a gente foi fazendo as percentagens, abordando né, os conceitos, tudo.

Ahmmm... Os alunos foram vendo que tava a notícia tava tendenciosa para o governo né. Pra, pra beneficiar o governo em questão né, então. Mas assim eu não saio do assunto da área de economia, de finanças, dessas coisas não!

Pesquisadora: Mas ôh professora, por exemplo os temas que são tratados dentro de sala de aula ensinando os licenciando, eles conseguem aplicar depois pro Ensino Fundamental ou Ensino Médio? É tratado isso?

Entrevistada: Então a gente tenta fazer isso né, vai abordar um juros compostos, então como que ele abordaria isso antes associando a progressão geométrica, é a parte de porcentagem que dá para fazer com a parte de potencia, humm...

Conceitos mesmo quando ele vai ensinar no ensino fundamental dá pra fazer por regrinha de 3 e não necessariamente pela fórmula, ou a parte de juros simples, éeee...

A gente tenta mostrar o raciocínio né e falar pra eles ensinarem de um jeito que não vai direto na fórmula né e se possível, associar com outros conceitos dos alunos. Mas, não sei se eles fazem isso no dia a dia! Risos... Mas essa é a intenção.

Pesquisadora: Ehhh, professora, você acha que mesmo depois de ter dado, você caracteriza a disciplina de Educação Financeira igual a de Matemática Financeira, ou não? 
Entrevistada: Olha, eu tenho umas diferenças que são essas diferenças de tentar associar. Não só não só dar conceitos né, não só dar a parte teórica da Matemática Financeira e sim associar notícias do dia a dia e relacionar com outras teorias da matemática.

Então eu acredito que há um pouquinho diferente.

Pesquisadora: Hum entendi. São discutidos temas como por exemplo endividamento, cartão de crédito, parcelamento?

Entrevistada: Isso! E assim, quando eles compram, compram uma moto e financia e aí traz carnê, ah professora, olha o que aconteceu! ... Aí a gente usa de exemplo na sala entendeu? Então são coisas assim, relacionadas ao dia a dia deles mesmo!

Pesquisadora: Entendi! Você acha que a disciplina possibilita para as pessoas que estão aprendendo mesmo os próprios licenciando a tomada de decisão um pouco mais consciente? Entrevistada: Ahhh, sim!

Pesquisadora: Você acredita que sim?

Entrevistada: Que a gente vê a surpresa deles assim quando você fala sobre a inflação, como que é calculado a taxa, aí eles falam: Nossa! Por isso que é aquele absurdo a taxa que a gente nunca sabe de onde saí! Né.

Ah e quando vai para as tabelas de financiamento, que a gente pega exemplos da Caixa, faz a simulação no computador e traz pra sala de aula pra mostrar, então eles..., eu acho que deixa os alunos mais conscientes na hora de fazer alguma, tomar alguma decisão.

Pesquisadora: Entendi.

Entrevistada: Sim.

Pesquisadora: E uma pergunta professora, sobre a ENEF, a senhora tem alguma opinião sobre a ENEF? A composição da ENEF, quem compõe, quem prepara o material e tudo mais?

Entrevistada: Hummmm, não tenho nenhuma opinião em particular, assim!

Pesquisadora: Tá.

Entrevistada: Risos... 
Pesquisadora: É porque a ENEF, ela é composta por bancos né, reguladores e assim eles preparam materiais de conscientização para a população e agora eles estão sendo fornecidos em meio que em sala de aula também. E aí se o professor que não teve Educação Financeira e utilizar aquele material, será que ele vai realmente fazer a conta, entender e criar toda aquela questão da conscientização financeira de fato?

Entrevistada: Só com o material?

Pesquisadora: É, sem nada na formação porque por exemplo hoje no curso de licenciatura do IME USP a gente não tem a disciplina como obrigatória nem Educação Financeira nem Matemática Financeira...

Entrevistada: Hum...

Pesquisadora: ...E aí, a gente indo para dentro de uma sala de aula como que a gente ensinaria essa questão da Educação Financeira?

Entrevistada: Entendi. Teria que ir atrás de material né! Aí esses daí são os que estão disponíveis...

Pesquisadora: Isso!

Entrevistada: Ah, eu não sei, eu acho que também vai da consciência da própria pessoa né! Que vai passar, vai ler e vai passar isso adiante né...

Pesquisadora: Entendi. E não tem nenhum motivo muito específico, professora, exatamente nesse campus ter a disciplina de Educação Financeira? Porque assim, em nenhum outro campus têm, com este nome não tem!

Entrevistada: Aham.

Pesquisadora: Vocês são os únicos.

Entrevistada: Hum não! O específico mesmo foi pra trazer para o departamento! Pros professores da licenciatura poderem dar pro curso de licenciatura porque eram os engenheiros que davam essa matéria né!

Pesquisadora: Entendi.

Entrevistada: Era muito técnico assim! 
Pesquisadora: Então até dentro de sala de aula você consegue ver que muda um pouco a postura dos alunos aprendendo um pouco mais de Educação Financeira?

Entrevistada: Hum, acredito que sim, acredito que sim!

Pesquisadora: Ah, interessante! 


\section{REFERÊNCIAS BIBLIOGRÁFICAS}

AEF - Associação de Educação Financeira do Brasil. Disponível em: $<$ http://www.aefbrasil.org.br/index.php/programas-e-projetos/educacao-financeira-nasescolas/ >. Acesso 15 dez. 2018.

ALMEIDA, A. C. (2004) Trabalhando Matemática Financeira em uma sala de aula do ensino médio da escola pública. Dissertação (Mestrado em Educação), Campinas: UNICAMP.

ARAÚJO, Carlos Roberto Vieira. Matemática Financeira: uso das mini calculadoras HP12C e HP19BI. São Paulo: Atlas, 1992.

ARAÚJO, M. B. S; PAIVA, E. P.; AUTRAN, M. M. M.; RAMALHO, F. A; DUARTE, E. N. Estratégias Metodológicas Adotadas nas pesquisas de Iniciação Cientifica premiadas na UFPB. Florianópolis, v. 14, n. 27, p.170-190, 2009.

BANCO MUNDIAL. Disponível em: <http://www.vidaedinheiro.gov.br/wpcontent/uploads/2017/04/avaliacao_educacao_financeira_escolas.pdf $>$. Acesso 15 dez. 2018 .

BAUMAN, Z. Vida para consumo. São Paulo: Zahar, 2008.

BRASIL. Base Nacional Comum Curricular: Educação Infantil e Ensino Fundamental. Brasília: MEC/Secretaria de Educação Básica, 2017.

BRASIL. Base Nacional Comum Curricular: Educação Infantil e Ensino Fundamental. Brasília: MEC/Secretaria de Educação Básica, 2018.

BRASIL. Base Nacional Comum Curricular: Ensino Médio. Brasília: MEC/Secretaria de Educação Básica, 2018.

BRASIL. Base Nacional Comum Curricular: Ensino Médio. Brasília: MEC/Secretaria de Educação Básica, 2018. GERALDI, J.

BRASIL. Secretaria da Educação Fundamental - Parâmetros Curriculares Nacional: introdução aos parâmetros curriculares nacionais. Brasília: MEC, 1997.

CAMPOS, A. KISTEMANN JR., M. A. Qual Educação Financeira queremos em nossa Sala de Aula. Revista Educação Matemática em Revista, v.40, p.48-56, 2013.

CAMPOS, C. R; COUTINHO, C. Q; TEIXEIRA, J.; Reflexões sobre a Educação Financeira e suas interfaces com a educação matemática e a educação critica. Edu. Matem. Pesqui., São Paulo, v.17, n.3, pp. 556-577, 2015.

CAPRONI, I. S.; A Importância da Educação Financeira na formação do educando, 2014. 
CNE - CONSELHO NACIONAL DE EDUCAÇÃO. Disponível em: $<$ http://portal.mec.gov.br/docman/agosto-2017-pdf/70431-res-cne-cp-002-03072015pdf/file $>$. Acesso 16 jun. 2018.

COUTINHO, C. Q; TEIXEIRA, J.; Letramento Financeiro: Um Diagnóstico de Saberes Docentes. REVEMAT, v.10, n.2, p. 1-22, 2015.

CRESWELL, J. W. W. Projeto de pesquisa: métodos qualitativo, quantitativo e misto. 2. ed. Porto Alegre: Bookman, 2010.

D’AQUINO, C. Educação Financeira: como educar seu filho. Rio de Janeiro: Elsevier, 2008.

DATA POPULAR. Disponível em: <http://www.vidaedinheiro.gov.br/wpcontent/uploads/2017/08/Plano-Diretor-ENEF-anexos-ATUALIZADO_compressed.pdf $>$. Acesso 15 dez. 2018.

ENEF - Estratégia Nacional e Educação Financeira. Disponível em: $<$ http://www.vidaedinheiro.gov.br/enef/ > . Acesso 18 set. 2017

GALLERY, N.; GALLERY, G.; BROWN, K.; PALM, C. Financial literacy and pension investment decisions. Financial Accountability \& Management.EUA, v. 27, n. 3, p. 286-307, 2011.

FRASER, M.T.D.; GONDIM, S.M.G. Da fala do outro ao texto negociado: discussões sobre a entrevista na pesquisa qualitativa. Paidéia, v.14, n.28, p.139-152, mai./ago. 2004.

GIL, A. C. Métodos e técnicas de pesquisa social. 5.ed. São Paulo: Atlas, 1999.

HAGUETTE, Teresa Maria Frota. Metodologias qualitativas na Sociologia. 5a edição. Petrópolis: Vozes, 1997.

HOFMANN, R; MORO, M. L.. Educação Matemática e Educação Financeira: perspectivas para a ENEF. Zetetiké - FE/Unicamp - v.20, n.38 - jul/dez. 2012.

KISTEMANN JR., M. A. Sobre a produção de significados e a tomada de decisão de indivíduos-consumidores. Tese de Doutorado. Programa de Pós-graduação em Educação Matemática, Instituto de Geociências De Ciências Exatas, Campus de Rio Claro, Universidade Estadual Paulista, Rio Claro, 2011.

LDB - Leis de Diretrizes e Bases. Lei no 9.394. 1996. Disponível em: $<$ http://portal.mec.gov.br/seesp/arquivos/pdf/lei9394_ldbn1.pdf >. Acesso 02 nov. 2018 LELIS, M. G. Educação Financeira e empreendedorismo. Centro de Produções Técnicas, 2006.

LIBÂNEO, J. C. Adeus professor, adeus professora?: novas exigências educacionais e profissão docente. São Paulo: Cortez, 1998.

MONARCHA, Carlos. Escola normal da praça: o lado noturno das luzes. Campinas: Editora da UNICAMP, 1999. 
NETO, ALMEIDA, A. KISTEMANN JR., M. D. I. Uma experiência com Educação Financeira de jovens indivíduos consumidores no PRÓBIC-JR-FAPEMIG/UFJF. Revista Paranaense de Educação Matemática, v.6, n.10, p.223-245, 2017.

OCDE - ORGANIZAÇÃO DE COOPERAÇÃO E DE DESENVOLVIMENTO ECONÔMICO OECD's Financial Education Project. 2005. Disponível em: $<$ http://www.oecd.org $>$. Acesso 30 de ago. 2017.

PCN - Parâmetros Curriculares Nacionais. Disponível em: $<$ http://www.educacional.com.br/legislacao/leg_vi.asp >. Acesso 02 out. 2018

PEPPE, L. Perspectiva da Educação Financeira: uma análise didática. Anais do XIX Encontro Brasileiro de Estudantes de Pós-Graduação em Educação Matemática- XIX EBRAPEM. Juiz de Fora, 2015.

POPULAR. A Educação Financeira no Brasil: relatório quali-quanti. 2008.

PROJETO DE LEI - Projeto de Lei n. 4915, de 2016. Disponível em:< https://www.camara.leg.br/proposicoesWeb/prop_mostrarintegra;jsessionid=01B94CA194 0797C251481F91D09470F2.proposicoesWeb1 codteor $=1449953 \&$ filename $=$ Avulso +PL+4915/2016>. Acesso 15 nov. 2019.

PEPPE, L. Perspectiva da Educação Financeira: uma análise didática. Anais do XIX Encontro Brasileiro de Estudantes de Pós-Graduação em Educação Matemática- XIX EBRAPEM. Juiz de Fora, 2015.

S\&P - S\&P Global Financial Literacy Survey. Disponível em: < https://gflec.org/wpcontent/uploads/2015/11/Finlit_paper_16_F2_singles.pdf $>$.Acesso 16 mar. 2018.

SAVIANI, D. Formação de professores: aspectos históricos e teóricos do problema no contexto brasileiro. Revista Brasileira de Educação, v.14, n.40, 2009

SAVOIA, José Roberto, SAITO, Andre Taue, SANTANA, Flávia de Angelis. Paradigmas da Educação Financeira no Brasil. Rev. Admin. Pública, Nov. Dec. 2007, vol 41, no.6, p. 1121-1141.

SELLTIZ, C.; WRIGHTSMAN, L. S.; COOK, S. W. Métodos de pesquisa das relações sociais. São Paulo: Herder, 1965.

SKOVSMOSE, O. Desafios da Reflexão em Educação Matemática Crítica. Coleção Perspectivas em Educação Matemática; Campinas - SP: Papirus, 2008.

SKOVSMOSE, O. Educação matemática crítica: A questão da democracia. 5 ed. Campinas, SP: Papirus, 2001. (Coleção Perspectivas em Educação Matemática)

TANURI, L. História da formação de professores. Revista Brasileira de Educação, n.14, 2000. 
VIDAL, D. G; (1995). O exercício disciplinado do olhar: livros, leituras e práticas de formação docente no Instituto de Educação do Distrito Federal (1932-1937). Tese de Doutorado em Educação. Faculdade de Educação da Universidade de São Paulo. 